\title{
The distribution of neuronal primary cilia immunoreactive to melanin- concentrating hormone receptor 1 (MCHR1) in the murine prosencephalon
}

\author{
Giovanne B. Diniz ${ }^{a, \#, ~ D a n i e l l a ~ S . ~ B a t t a g e l l o ~}{ }^{a}$, Bianca S. M. Bono ${ }^{b}$, Jozélia G. P. Ferreira ${ }^{a}$, Marianne O. Klein ${ }^{a}$, \\ Livia C. Motta-Teixeiraa, Jessica C. G. Duarte ${ }^{a}$, Françoise Pressec, Jean-Louis Nahon' ${ }^{c}$, Antoine \\ Adamantidis $^{d}$, Melissa J. Chee $^{\mathrm{b}}$, Luciane V. Sita $^{\mathrm{a}}$ and Jackson C. Bittencourtt ${ }^{\mathrm{a}, \mathrm{e}}{ }^{*}$
}

\footnotetext{
a University of Sao Paulo, Institute of Biomedical Sciences, Department of Anatomy, Sao Paulo, SP, Brazil.

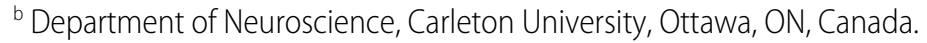

'Université Côte d'Azur, CNRS, Institut de Pharmacologie Moléculaire et Cellulaire (IPMC), Valbonne, France.

d Department of Neurology, Inselspital, University of Bern, Bern, Switzerland.

e University of Sao Paulo, Institute of Psychology, Center for Neuroscience and Behavior, Sao Paulo, SP, Brazil.
}

\# This author current address is: FMB 421, Department of Neurosurgery, Yale School of Medicine, New Haven, CT 06520, USA.

* Corresponding author:

Jackson Cioni Bittencourt, M.D., Ph.D.

Laboratory of Chemical Neuroanatomy

Department of Anatomy

Institute of Biomedical Sciences

University of São Paulo

São Paulo, Brazil - ZIP: 05508-000

Phone: +55 (11) 30917300

E-mail: jcbitten@icb.usp.br

Working title: Ciliary MCHR1 in murines

Keywords: MCH; volume transmission; olfactory integration; neurochemical characterization; GPCR.

Funding: Financial support for this study was provided in the form of grants from the Fundação de Amparo à Pesquisa do Estado de São Paulo (FAPESP, São Paulo Research Foundation; Grants \# 2016/02748-0 to G.B.D., 2015/05990-4 and 2016/19845-9 to J.G.P.F., 2017/17998-5 to M.O.K., 2014/22313-3 and 2016/18941-4 to L.C.M.-T., and 2016/02224-1 and 2017/16293-8 to J.C.B.). We are thankful for the support provided by the Brazilian Coordenação de Aperfeiçoamento de Pessoal de Nível Superior (CAPES, Office for the Advancement of Higher Education, Grant CAPES/COFECUB \#848/15). D.S.B. is a fellowship recipient of PNPD/CAPES, Brazil). J.C.B. is an Investigator with the Brazilian Conselho Nacional de Desenvolvimento Científico e Tecnológico (CNPq, National Council for Scientific and Technological Development, grant \# 426378/2016-4). M. J. C. is a recipient of NSERC Discovery Grant RGPIN-2017-06272. This work was supported by the CNRS, the "Fondation pour la Recherche Médicale" (FRM DEQ20150331738), the Medisite Foundation and by the French government, managed by the National Research Agency (ANR), through the UCA JEDI Investments in the Future project with reference number ANR15-IDEX-01 and the LABEX SIGNALIFE program with reference number ANR-11-LABX-0028-01. We would also like to acknowledge support provided to A.A. by the Human Frontier Science Program (RGY0076/2012), Inselspital University Hospital, the University of Bern, Swiss National Science Foundation (156156), and the European Research Council (ERC-2016-COG-725850). 


\section{Abstract}

Melanin-concentrating hormone $(\mathrm{MCH})$ is a ubiquitous vertebrate neuropeptide predominantly synthesized by neurons of the diencephalon that can act through two G protein-coupled receptors, called MCHR1 and MCHR2. The expression of Mchr1 has been investigated in both rats and mice, but its synthesis remains poorly described. After identifying an antibody that detects MCHR1 with high specificity, we employed immunohistochemistry to map the distribution of MCHR1 in the CNS of rats and mice. Multiple neurochemical markers were also employed to characterize some of the neuronal populations that synthesize MCHR1. Our results show that MCHR1 is abundantly found in a sensory subcellular structure called the neuronal primary cilium, which has been associated with the detection of free neurochemical agents released to act through volume transmission. Ciliary MCHR1 was found in a wide range of areas, including the olfactory bulb, cortical mantle, striatum, hippocampal formation, amygdala, midline thalamic nuclei, periventricular hypothalamic nuclei, and midbrain areas. No differences were observed between male and female mice, and rats and mice diverged in two key areas: the caudate-putamen nucleus and the subgranular zone of the dentate gyrus. Ciliary MCHR1 was found in close association to several neurochemical markers, including tyrosine hydroxylase, calretinin, kisspeptin, estrogen receptor, oxytocin, vasopressin, and corticotropinreleasing factor. Given the role of neuronal primary cilia in sensing free neurochemical messengers in the extracellular fluid, the widespread distribution of ciliary MCHR1, and the diverse neurochemical populations who synthesize MCHR1, our data indicates that volume transmission may play a prominent role in the normal function of the MCH system. 


\section{Introduction}

Melanin-concentrating hormone $(\mathrm{MCH})$ is a ubiquitous vertebrate neuropeptide, synthesized predominantly by neurons of the diencephalon and, in particular, of the lateral hypothalamic area (Bittencourt \& Diniz 2018; Bittencourt et al. 1992). The MCH neuropeptidergic system has been involved in several physiological roles, including the integration and promotion of motivated behaviors (Diniz \& Bittencourt 2017), modulation of energy expenditure (Qu et al. 1996; Chee et al. 2019), sleep (Ferreira et al. 2017a; Gao 2018), ventricular homeostasis (Conductier et al. 2013b; Conductier et al. 2013a), and autonomic function modulation (Brown et al. 2007; Messina \& Overton 2007). It has also been implicated in reproductive physiology (Naufahu et al. 2013), including the release of luteinizing hormone (Chiocchio et al. 2001; Murray et al. 2000b), the promotion of sexual behavior (Gonzalez et al. 1996), and parental behavior (Alachkar et al. 2016; Benedetto et al. 2014).

The mammalian MCH peptidergic system is composed by three peptides produced from a single precursor, encoded by the Pmch gene. In addition to MCH, neuropeptide E-I (NEI) and neuropeptide G-E (NGE) are cleaved by prohormone convertases and may have biological activities that are independent of $\mathrm{MCH}$ (Bittencourt \& Celis 2008). This system is also composed by two receptors that bind with specificity to $\mathrm{MCH}$, called $\mathrm{MCH}$ receptor 1 (MCHR1) and receptor 2 (MCHR2) (reviewed in Presse et al. (2014) and Bittencourt and Diniz (2018)). While MCHR1 is present in a wide range of vertebrates, MCHR2 has been lost after the divergence of the Glires clade, what resulted in the loss of a working MCHR2 receptor in rabbits, guinea pigs, hamsters, rats and mice (Tan et al. 2002). As a result, the amount of information amassed about MCHR1 is significantly higher than that about MCHR2.

Despite the focus on MCHR1, there are a few important aspects of this receptor that are not well understood. After the discovery of MCH as the ligand of MCHR1 (Bächner et al. 1999; Chambers et al. 1999; Saito et al. 1999; Shimomura et al. 1999), the distributions of Mchr1 gene expression and MCHR1 immunoreactivity were described in rats (Saito et al. 2001; Hervieu et al. 2000). In both cases, only male specimens were used, and both works describe widespread expression/synthesis of MCHR1. The next wave of works then focused on mice, through the use of gene reporters (Chee et al. 2013; Engle et al. 2018). Despite an exhaustive investigation and detailed description of the gene reporter distribution, the experimental model of gene reporters cannot inform the subcellular localization of the protein product that results from the investigated gene. It is unclear, therefore, what is the precise subcellular localization of MCHR1 in vivo.

The first hint that the subcellular localization of MCHR1 may be important for its function came in the work of Berbari et al. (2008), who described MCHR1 immunoreactivity in the primary cilia of cultured cells, and in a few areas of the central nervous system. Primary cilia are non-motile structures, found within the CNS exclusively in neurons, and first described in humans (Mandl \& Megele 1989). The main role of primary cilia is chemical sensing and signal transducing (Pazour \& Witman 2003; Berbari et al. 2009), as they are covered in receptors (Händel et al. 1999; Brailov et al. 2000; Loktev \& Jackson 2013; Koemeter-Cox et al. 2014; Siljee et al. 2018), and participate in several signaling pathways (Breunig et al. 2008; Rohatgi et al. 2007; Corbit et al. 2005). Neuronal primary cilia may be an integral part of volume transmission (VT), a neuronal method of communication that involves the use of neurochemical messengers outside the synapse (Agnati et al. 1986; Agnati et al. 1995; Agnati et al. 2010), including the release of neuroactive substances in the extracellular space (ECS) and the cerebrospinal fluid (CSF) (Fuxe et al. 2007; Agnati \& Fuxe 2014).

Mapping the areas where MCHR1 is associated to primary cilia in the CNS may help us understand its mechanisms of action. It has recently been demonstrated that MCH acts in a VT paradigm to exert a modulatory role in feeding (Noble et al. 2018; Jiang \& Brüning 2018). Areas linked to feeding behavior where MCHR1 is ciliary are the likely target for this effect. Furthermore, areas unrelated to feeding behavior that contain ciliary MCHR1 may reveal clues about other actions exerted by 
MCH that depend on VT. With that in mind, we mapped the presence of MCHR1 immunoreactivity in cilia in the prosencephalon of adult rats and mice. Since MCH has been implicated in sexual regulation (Gonzalez et al. 1996; Murray et al. 2000b; Murray et al. 2006; Wu et al. 2009), and female models have been poorly explored in the literature concerning MCH, we included females in all four estrous cycle stages to evaluate possible changes in the receptor distribution linked to reproductive status. The results found in mice were then compared to rats to inform us about possible interspecies differences in the distribution of MCHR1.

\section{Materials and Methods}

\subsection{Animals}

Adult male and female virgin C57BL/6 mice $(n=25)$ were bred and raised in the animal facility of the Department of Anatomy, Institute of Biomedical Sciences of the University of São Paulo. At the beginning of the experiments, animals were approximately three months old and weighed between 20 and 30g. Females were housed five per cage, while males were housed individually after they reached sexual maturity, in a room with 12/12h light/dark cycle (lights on at 6:00 AM), controlled temperature $\left(22 \pm 2^{\circ} \mathrm{C}\right)$, and ad libitum access to water and standard chow. All experiments were carried out in accordance with the Guidelines for the Care and Use of Mammals in Neuroscience and Behavioral Research established by the Brazilian National Research Council (CONCEA, 2016), as well as with those established by the Ethics Committee on the Animal Use of the Institute of Biomedical Sciences (Protocol CEUA \#096/2014). No effort was spared to minimize the number of animals employed in this study and any incidental suffering caused to them. To evaluate the possibility that interspecies differences exist in the distribution of MCHR1, adult male Sprague-Dawley rats $(n=5)$ were bred and raised as described above. To test antibody specificity, we employed Mchr1\%- mice (Adamantidis et al. 2005), as well as their heterozygous and WT littermates. These animals were bred and raised in the animal facility of the University Hospital, Inselspital, in Bern, Switzerland in conditions similar as above.

To determine the day of euthanasia, females had their estrous cycle checked daily at 10:00 AM by the method of vaginal cytology (Byers et al. 2012). To that end, 50 $\mathrm{\mu l}$ of saline were inserted in the vaginal channel with a pipette and gel-loading tips. Care was taken so the tip did not touch the vagina to avoid unintended stimulation and pseudopregnancy. The liquid was then collected, spread on glass slides, and examined under the light microscope (Nikon Corporation; Minato, Tokyo, Japan). Estrous cycle determination was based on the relative densities of epithelial, cornified, and leucocyte cell populations (Byers et al. 2012).

\subsection{Tissue collection}

At the day of euthanasia, animals were anesthetized with an excess of Xylazine, Ketamine and Acepromazine. Once verified the loss of reflexes, animals were thoracotomized and transcardially perfused. For mice, approximately $20 \mathrm{ml}$ of cold $0.9 \%$ saline solution were perfused to clean the vascular bed, followed by $240 \mathrm{ml}$ of $4 \%$ formaldehyde solution in borate buffer (pH 9.5). In rats, the volume was $100 \mathrm{ml}$ of cold $0.9 \%$ saline and $750 \mathrm{ml}$ of $4 \%$ formaldehyde solution in borate buffer (pH 9.5). After perfusion, the heads were separated from the body, the cranium opened, and the brain removed and post-fixed in the same fixative solution with $20 \%$ sucrose for four hours. At the end of the postfixation time, brains were transferred to $0.02 \mathrm{M}$ potassium-phosphate buffered saline (KPBS, pH 7.4) with $20 \%$ sucrose at $4^{\circ} \mathrm{C}$ until slicing. Slicing of the brains was performed in the frontal plane in a sliding microtome. One-in-five series of 20 $\mu \mathrm{m}$ slices were obtained from mice and one-in-five series of $40 \mu \mathrm{m}$ were obtained from rats. Slices were kept in antifreeze solution at $-30^{\circ} \mathrm{C}$ until immunohistochemistry.

\subsection{Immunohistochemistry}

\subsubsection{Antibody selection}


To identify an antibody that selectively labels MCHR1, we tested six brands of commercially-available antibodies. The details of each antibody are listed in Table 1. Each antibody was used for immunoperoxidase staining in six different dilutions $(1: 1,000,1: 3,000,1: 10,000,1: 30,000,1: 100,000$ and 1:300,000), as described by Hoffman et al. (2016) for antibody titration. In some cases, where no signal whatsoever could be detected, we tested more concentrated titers (not shown). The concentration of antibody found to be optimal for immunoperoxidase staining was then used for immunofluorescence procedures. Primary and secondary antibody suppression tests were performed for all antibodies (not shown). The antibody that resulted in the best labeling was then further tested on tissue from knockout animals, negative control test described as the gold standard of antibody validation by Saper and Sawchenko (2003).

\subsubsection{Immunoperoxidase}

For immunoperoxidase staining, slices were extensively rinsed in KPBS for antifreeze solution removal and incubated with a $0.3 \%$ solution of hydrogen peroxidase in KPBS for 15 minutes. Slices were then rinsed again in KPBS and incubated with primary antibody in a KPBS solution of 3\% normal goat serum (Vector Laboratories; Burlingame, CA, USA; AB_2336615) and 0.3\% Triton X-100 for membrane permeabilization. In the following day, slices were rinsed in KPBS and incubated with biotinylated goat anti-rabbit IgG (1:800, Vector; $\left.A B \_2313606\right)$ for one hour at room temperature. After new rinses, slices were incubated with an avidin-biotin-horseradish peroxidase solution (1:333, Vector; AB_2336819) for one hour. For chromogen deposition, slices were transferred to a solution of 3,3'-diaminobenzidine tetrahydrochloride (DAB, 0.02\% - Sigma Chemical; St. Louis, MO, USA) with $0.003 \%$ hydrogen peroxide and $2.5 \%$ nickel ammonium sulfate diluted in $0.2 \mathrm{M}$ sodium acetate buffer ( $\mathrm{pH}$ 6.5). Reactions were stopped by transferring slices to clean sodium acetate buffer and then rinsing them with KPBS. Sections were then mounted on gelatin-coated glass slides in rostrocaudal order, dehydrated, defatted and coverslipped with a hydrophobic mounting medium (DPX; Sigma).

\subsubsection{Immunofluorescence}

For immunofluorescence staining of MCHR1, a protocol similar to that described by Hoffman et al (2016) was employed. Briefly, slices were rinsed in KPBS and incubated with a $0.3 \%$ solution of hydrogen peroxidase in KPBS for 20 minutes. After new rinses, slices were incubated with primary antibody in a KPBS solution of 3\% normal donkey serum (Jackson ImmunoResearch; West Grove, PA, USA; AB_2337258) and 0.3\% Triton X-100 for membrane permeabilization. In the following day, slices were incubated with biotinylated donkey anti-rabbit IgG antibody (1:5000, Jackson ImmunoResearch; AB_2340593) for one hour at room temperature and then incubated with avidin-biotin-horseradish peroxidase solution (1:833, Vector; AB_2336819) for 30 minutes at room temperature. Slices were then washed and incubated with a 0.5\% biotinylated (EZ-Link sulfo-NHS-LC-biotin; ThermoFisher Scientific, Waltham, MA, USA) tyramine (Sigma-Aldrich; Sigma Chemical; St. Louis, MO, USA) and hydrogen peroxide (0.005\%) solution for 20 minutes, and then incubated with AlexaFluor 594-conjugated streptavidin (1:200, Invitrogen; Carlsbad, CA, USA). Slices were then rinsed in KPBS, incubated with DAPI (1:10'000, Invitrogen) for 10 minutes and mounted in glass slides or used in following labeling experiments.

To label other markers, MCHR1-immunolabeled slices were rinsed with KPBS and incubated with primary antibodies for different neurochemical markers (Table 1) in KPBS containing 3\% normal donkey serum (Jackson ImmunoResearch; AB_2337258) and 0.3\% Triton X-100. In the following day, slices were rinsed and incubated with AlexaFluor 488-conjugated donkey anti-IgG antibodies (1:200, Invitrogen; AB_2556546, AB_2534082, AB_2556542, AB_2534102) for two hours at room temperature. After final rinses with KPBS, slices were mounted in glass slides. After a brief period of air drying, the slides were then covered with antifade mounting medium (Invitrogen) and coverslipped. 


\subsection{Imaging and Data Analysis}

Immunoperoxidase-labeled slices were examined with brightfield microscopy in a Nikon 80i microscope (Nikon) coupled to a digital camera (CX3000 - MBF Bioscience Co.; Williston, VT, USA) and operating under the software Microlucida 3.03 (MBF Bioscience). Immunofluorescence-labeled slices were examined with widefield and confocal fluorescence microscopy in an Axiolmager Z2 motorized upright microscope (Carl Zeiss; Wetzlar, Germany). Widefield illumination was obtained with an HXP 120V illuminator (Carl Zeiss) and photomicrographs were produced with an AxioCam 506c (Carl Zeiss). Each fluorophore was imaged separately in emulated monochromatic mode in separate channels and then merged. Confocal microscopy was performed using a laser unit as light source and the LSM800 scan unit with two metal halide detectors (Carl Zeiss). All images had adjustments in their brightness, contrast, and sharpness applied to every pixel in the picture, and the changes did not alter the information illustrated in the figures. The plates were assembled, and off-tissue background/methodological artifacts were cleared by means of Adobe Photoshop CC 2017.0.1 software (Adobe Systems Inc; San Jose, CA, USA; SCR_014199).

Mapping of MCHR1 immunoreactivity was performed by comparing the cytoarchitectonic characteristics of each slice, as evidenced by DAPI staining (when applicable), to the atlas of Paxinos and Franklin (2012) and Paxinos and Watson (2006). In some cases, additional information was obtained using neurochemical markers to delineate specific areas. The comparison of relative densities between male and female and between different estrous cycle stages was performed using a semi-quantitative method. After analysis of random slices, a scale of cilia density was developed. An investigator blind to the experimental condition of the animals then used the scale to rate the presence of immunoreactive cilia in each area examined with a number ranging from $0-8$, with 0 corresponding to complete absence of immunoreactivity and 8 corresponding to the highest density found. The same procedure was performed for all animals and the average density of cilia was obtained for each area and each sexual status. To facilitate the presentation of these results, the number system was then converted to a system of crosses with less discrimination but better noise suppression.

\section{Results}

\subsection{The antibody used targets ciliary MCHR1 with high specificity}

From the six antibodies tested for MCHR1 detection (Table 1), only one resulted in consistent labeling at the tested concentrations: antibody PA5-24182 from Invitrogen. Antibody Santa Cruz C-17 (Table 1) also resulted in staining, but the lower signal/background ratio and the discontinuation of this antibody by its manufacturer led us to use antibody PA5-24182 in the rest of the experiments. Because antibody PA5-24182 has never been used in the literature, we proceeded to verify its specificity by employing standard omission tests and using tissue from $\mathrm{MChr}^{--/}$and $\mathrm{Mchr}^{+/-}$mice (Saper \& Sawchenko 2003). As expected, antibody and fluorophore omission tests were successful, with no staining observed in the antibody suppression cases (Fig. 1 $\left.\mathrm{A}^{\prime}-\mathrm{A}^{\prime \prime}\right)$. Using the antibody on tissue from $\mathrm{MChr}^{+}$animals resulted in the regular pattern of staining observed during titrations

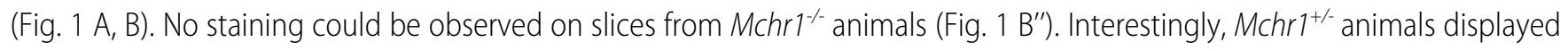
an intermediate pattern of staining, with scattered labeling found in areas otherwise heavily labeled in $\mathrm{Mchr}^{+}$animals (Fig. 1 $\left.\mathrm{B}^{\prime}\right)$. These tests show that the used MCHR1 antibody labels its target with high specificity.

To confirm the labeling observed using the PA5-24182 was ciliary, we performed double immunohistochemistry in series of some animals using an anti-adenylate cyclase III (AC3) antibody. Adenylate cyclase III has been shown to be a marker of neuronal primary cilia (Bishop et al. 2007). As expected, we found widespread staining for AC3, agreeing to the distribution described by Bishop et al (2007). In several areas, colocalization between MCHR1 and AC3 was almost complete, such as in the pyramidal layer of the hippocampus proper (Fig. 2 A), while in others there was no signal of MCHR1 colocalizing with the AC3positive labeling, such as in the granular layer of the dentate gyrus (Fig. 2 B). Upon closer inspection, it was observed that MCHR1 labeling seldom covers the whole cilia, in most cases forming a patched pattern upon the ciliary surface (Fig. 2 A'). As an 
additional control, we performed simultaneous MCHR1 and NeuN (neuronal marker) or GFAP (glial marker) labeling. Since neuronal primary cilia are not found in glial cells, we expected no clear pattern of co-distribution between MCHR1 and GFAP. As expected, no clear pattern was observed, while MCHR1 was found codistributed with NeuN in several areas (Supplementary Material 01).

\subsection{MCHR1 is widely distributed within the murine prosencephalon}

To map the distribution of MCHR1 in the mouse prosencephalon, we developed a grading scale that went from 0 (complete absence of staining) to 8 (maximum density of weight) (Fig. 3). Each area identified using the mouse brain atlas by Paxinos and Franklin (2012) from each animal was then scored based on that grading scale by a single experimenter, who was blind to the group of each animal. Upon comparison, there were no consistent differences between male and female and the different stages of the estrous cycle, and therefore only a stereotypical distribution contemplating all groups will be presented in this paper (Table 2). The distribution of MCHR1 in rats and mice was also highly similar, and therefore the mouse will be used to elaborate the description of the results, and differences between the two species will be highlighted at the end of this section. To simplify the description of the results, the numerical system implemented in the first analysis was simplified to a cross system, where a dash represents no staining and four crosses represent maximum staining (Fig. 3). Highlights of the morphological distribution of MCHR1-ir cilia in adult mice will be provided in this section, and some areas are illustrated in Fig. 4. For an exhaustive description, we ask the reader to refer to Table 2.

Labeling could be abundantly observed in olfactory areas, such as the olfactory bulb, including the glomerular and granular layers, internal plexiform layer and mitral cell layer; layer 2 of the piriform cortex; dorsal and ventral taenia tecta; dorsal and intermediate endopiriform nucleus; and olfactory tubercle. Albeit in a smaller density, we also observed labeling in the medial aspect of the anterior olfactory nucleus. Other subcortical areas were also rich in labeling. The region with the densest immunolabeling for MCHR1 was the shell of the nucleus accumbens, with a moderate density found in the core subdivision of this nucleus. The neighboring ventral pallidum also displayed high levels of MCHR1 immunoreactivity. In the caudate-putamen nucleus, a mediolateral gradient was observed in the matrix, with a high density found medially, close to the lateral ventricle walls. No staining was observed in the striasomes. Likewise, no staining was observed in the globus pallidus. In the adjoining septal nuclei, only sparse immunoreactivity was seen in the ventral part of the lateral septal nucleus, with no labeling detected in other subdivisions of the lateral septal nucleus or in the medial septal nucleus.

In the amygdaloid complex, scattered MCHR1 immunoreactivity was observed in the basolateral, basomedial, medial and central nuclei. The hippocampal formation displayed a very characteristic pattern of staining, with a high density of immunolabeled cilia in the pyramidal stratum of CA1, CA2, and to a lesser extent, CA3 of the hippocampus proper. Scattered immunoreactivity was found in strata Oriens and Radiatum. The cortical distribution of MCHR1 followed a clear layer-specific distribution, with high densities of MCHR1 found in layers 2, 3 and 5, lower densities found in layers 4 and 6, and no staining found in layer 1 (Supplementary Material 01). Among the cortical regions containing MCHR1-ir cilia elements are: orbital, granular and agranular insular cortex; primary and secondary somatosensory cortices; primary and secondary motor cortices; frontal, perirhinal and entorhinal cortices; temporal, visual and auditory cortices. In the cingulate cortex, we observed a decreased density of MCHR1-ir cilia in layers 2 and 3 when compared to other cortical areas.

In the diencephalon, MCHR1-ir cilia were observed in several thalamic areas, such as the parataenial nucleus, the paraventricular thalamic nucleus, medial thalamic nuclei, and the medial habenular nucleus. We did not observe immunoreactivity in the zona incerta. In the hypothalamus, scattered cilia can be found in the lateral zone, in addition to strong clusters of immunoreactive material in the preoptic periventricular nucleus, paraventricular hypothalamic nucleus, and arcuate 
nucleus. Average densities of cilia were found in the medial preoptic area, anterior hypothalamic area and the posterior hypothalamic area, while medial zone nuclei were mostly devoid of labeling, such as the dorsomedial hypothalamic nucleus and the ventromedial hypothalamic nucleus.

At first glance, the distribution of MCHR1-ir cilia appeared to be complementary to that of MCH- and NEl-ir fibers, with areas rich in immunoreactive fibers virtually devoid of MCHR1-ir cilia, while areas rich in the receptor receive sparse innervation (Diniz et al. 2019). To confirm this pattern, we performed double immunohistochemistry to visualize MCHR1 and MCH-ir fibers in the same slices. The resulting pattern of labeling confirmed the segregation between some MCH-ir fibers-rich areas and areas containing large amounts of MCHR1-ir cilia, such as the nucleus accumbens/medial septal nucleus boundary (Fig. 5), or the medial/lateral globus pallidus (not shown).

In rats, the general outline of staining was very similar to the one found in mice, including abundant staining in olfactory regions, chiefly the olfactory bulb and anterior olfactory nuclei, piriform cortex, olfactory tubercle, ventral pallidum and the islands of Calleja; the shell of the nucleus accumbens; layers 2, 3 and 5 of numerous cortical fields; the pyramidal stratum of the hippocampal formation; medial and central amygdaloid nuclei; midline thalamic nuclei and the periventricular and medial zones of the hypothalamus. Two notable differences, however, could be found between rats and mice. While mouse has a moderate-to-high staining of MCHR1 in the caudate putamen, rats were almost devoid of immunoreactivity is this area, with a very high background observed in the matrix. On the other hand, a negligible amount of MCHR1 immunoreactivity is observed in the mouse granular layer of the dentate gyrus, while a layer of stained cilia can be discerned in the subgranular zone of the rat dentate gyrus (Fig. 6).

\subsection{Defined neurochemical populations display ciliary MCHR1}

Because MCHR1-ir cilia were found in areas with heterogeneous neurochemical populations, we employed double immunohistochemistry to characterize some of those populations. In the olfactory bulb, MCHR1-ir cilia were found in a pattern that closely resembled the distribution of tyrosine hydroxylase-ir cells, bordering the glomeruli (Fig. 7 A, A'). To a lesser extent, MCHR1-ir cilia are found associated to calretinin-ir cells (Fig. 7 B, B'). On the other hand, no MCHR1-ir cilia were found within range of calbindin-ir cells (not shown). In the preoptic hypothalamus, we found MCHR1-ir cilia associated with kisspeptin-ir cells (Fig. 8 A, A') but not with gonadotropin-releasing hormone (GnRH)-ir cells. In the periventricular and medial preoptic nuclei, MCHR1-ir cilia were also encountered in close proximity to estrogen receptor a cells (Fig. 8 B, B').

In the paraventricular nucleus of the hypothalamus, MCHR1-ir cilia were densest in the parvicellular subdivisions, but immunoreactive cilia were also found in the magnocellular subdivisions. While there is no clear overlap on the MCHR1 and vasopressin distributions, MCHR1 is largely codistributed with oxytocin, mainly in the fringes of the magnocellular nuclei (Fig. 8 C, C'). A higher degree of colocalization was seen between MCHR1-ir cilia and corticotropin-releasing factor (CRF) in the parvicellular paraventricular nucleus (Fig. 8 D, D'). In the supraoptic nucleus, a different pattern was observed, with almost complete colocalization between MCHR1-ir cilia and vasopressinergic neurons, while only partial colocalization was found between MCHR1 and oxytocinergic neurons (Fig. $8 \mathrm{E}, \mathrm{E}^{\prime}$ ).

In the arcuate nucleus, we found no colocalization between MCHR1 and a-melanocyte-stimulating hormone (a-MSH) or cocaine- and amphetamine-regulated transcript (CART). The only clear codistribution observed in the arcuate nucleus was between MCHR1 and tyrosine hydroxylase (TH), a dopaminergic marker. The arcuate nucleus, however, was not the only area where TH and MCHR1 were extensively codistributed, as virtually every TH-ir neuron in the incerto-hypothalamic area has a corresponding MCHR1-ir cilium (Fig. 8 F, F'). Neurons immunoreactive to CART in the incerto-hypothalamic area and in the 
lateral hypothalamus did not contain MCHR1-ir cilia, and there was no clear codistribution of MCHR1 and orexin in the lateral hypothalamus. Finally, no colocalization was observed between doublecortin and MCHR1 in the canonical sites of adult neurogenesis in the mouse brain.

\section{Discussion}

The presence of ciliary MCHR1 in the prosencephalon of murines is more extensive than previously known. In this work, we identified a commercial antibody that is able to stain ciliary MCHR1 with high specificity, and we employed it to map the presence of MCHR1 in neuronal primary cilia of both rats and mice, including female mice in all four stages of the reproductive cycle. Our results show a ciliary MCHR1 distribution that includes a wide range of structures, from the olfactory bulb to the hypothalamic mammillary nuclei. Our results are in agreement to most of what has been published up to this point in terms of Mchr1 gene expression, suggesting ciliary MCHR1 is at least as abundant as, if not even more abundant, than other subcellular locations of MCHR1. The wide range of areas in which MCHR1 is found opens up the possibility that volume transmission may be a very important aspect of MCH cellular communication within the CNS, and an important aspect of neurochemical communication in vertebrate systems as a whole.

Up to this point, the staining of MCHR1 has been limited to a few works. Hervieu et al. (2000) were the first to use antibodies to map MCHR1, but there is no mention as to the subcellular localization of the labeling obtained by those authors. The other two published works that employed immunohistochemistry for MCHR1 were Berbari et al. (2008) and Niño-Rivero et al. (2019), who used a now discontinued antibody to demonstrate the presence of MCHR1 in the neuronal primary cilia of specific areas within the CNS of mice and rats. We demonstrated in this work that antibody PA5-24182 is a suitable replacement for the labeling of MCHR1, generating negative results in antibody omission tests, not labeling tissue from Mchr ${ }^{-1}$, and specifically labeling MCHR1 in neuronal primary cilia, as demonstrated by the colocalization with AC3. An additional benefit of the identified antibody is its target epitope. Directed at the last 27 residues of MCHR1, within the intracellular C-terminal portion of this receptor, this sequence is highly conserved between mammals, with a single conservative substitution in humans when compared to rodents, suggesting it may be successfully used to label MCHR1 in other mammals.

The distribution of MCHR1 obtained in this work is mostly similar, but not identical, to what has been described before. With respect to the immunohistochemical mapping of Hervieu et al. (2000) and the in situ hybridization mapping of Saito et al. (2001), several areas of the rat brain were also stained with antibody PA5-24182, including the olfactory tubercle, piriform cortex, endopiriform nuclei, hippocampal formation, amygdala, periventricular and paraventricular hypothalamic nuclei, arcuate nucleus, the cortical mantle and the midline thalamic nuclei. We also observed labeling in the olfactory bulb, islands of Calleja and in the medial habenular nucleus, areas that were also labeled in Hervieu et al. (2000), but not in Saito et al. (2001). On the other hand, Hervieu et al. (2000) described intense labeling of the medial septal nucleus and similar labeling of the hippocampus proper and the dentate gyrus, while this work and that of Saito et al. (2001) found an absence of MCHR1 synthesis and Mchr1 expression in the medial septal nucleus, and a much lower presence of MCHR1/Mchr1 in the dentate gyrus when compared to the hippocampus proper.

The differences in MCHR1 density between rats and mice observed in this work are partially coherent with previous works. Hervieu et al. (2000) found a medium density of MCHR1 in the caudate-putamen of rats, while Saito et al. (2001) found a low expression of Mchr1 in this area. Chee et al. (2013) found a medium-high density of Mchr1 reporter expression in mice. Our results align well with those of Chee et al. (2013) and Saito et al. (2001), as the mouse has a much more pronounced presence of MCHR1 cilia in the caudate-putamen. This is also the case with the dentate gyrus, as Saito et al. (2001) report a restricted presence of Mchr1 expression in this structure, and Chee et al. (2013) found no Mchr1 mRNA expression. To what extent these 
interspecies differences results in physiological differences is still unknown. Rats and mice have different profiles in terms of generation of new neurons in the hippocampus and their integration into functional circuits (Snyder et al. 2009), and the site of MCHR1 synthesis in rats found in this work is the subgranular zone, area thoroughly implicated in adult neurogenesis (Eriksson et al. 1998). Rats and mice also show different social responses to cocaine (Kummer et al. 2014), what could have as substrate differences in the caudate-putamen nucleus. To determine to what extent MCHR1 is involved in those differences more studies will be necessary.

Gene reporters and in situ hybridization have been used to investigate the expression of Mchr1 in the mouse brain (Chee et al. 2013; Engle et al. 2018). Our distribution of MCHR1 immunoreactivity is mostly similar to what has been described in those works, including the olfactory areas, a similar pattern of cortical distribution, very dense labeling of the islands of Calleja, preeminent labeling in the pyramidal layer of the hippocampal formation and induseum griseum, no labeling of the medial septal nucleus, low labeling of thalamic nuclei, and weak to moderate labeling of the zona incerta and amygdala. The major disagreement between our work and that of Chee et al. (2013) concerns the relative density of synthesis/expression in some hypothalamic nuclei: while gene expression was highest in the arcuate nucleus and only moderate in the paraventricular and supraoptic nuclei, we found average synthesis in the arcuate nucleus and a very dense labeling density in the paraventricular and supraoptic nuclei. These disagreements likely stem from the inherent differences between the methods employed. Detection of Mchr1 expression in the gene reporter model depends on the strength of Cre expression in the Mchr1-Cre lineage, which often is less than 100\%, resulting in neurons who are not detected despite expression of Mchr1. Furthermore, the density of Cre-positive neurons in gene reporter models cannot be correlated directly with protein synthesis, limiting a precise interpretation of MCHR1 function. Curiously, Engle et al. (2018) report that the level of Mchr1 expression in the arcuate and paraventricular nuclei varied significantly between animals with inducible versus constitutive Mchr1-Cre alleles, suggesting that transient expression of Mchr1 may occur during development at critical windows, possibly resulting in the variations observed between our animals and previous studies.

The labeling obtained in this work was entirely ciliary, as revealed by the full colocalization between MCHR1 and AC3 in all areas examined. It is unclear, at this moment, if this results from all MCHR1 being found solely at primary cilia, or if the antibody targets ciliary MCHR1 selectively, either due to slight post-translational differences between ciliary and non-ciliary MCHR1 or due to facilitated antibody access to its epitope in the cilium as compared to the membrane or synaptic space. Hervieu et al. (2000) found labeling with anti-MCHR1 to be confined to the plasma membrane, indicating that the antibody used in that work targets specifically membrane MCHR1, while both Berbari et al. (2008) and Niño-Rivero et al. (2019) found labeling to be exclusively ciliary. Regardless of the case, our work demonstrates that MCHR1 presence in the cilium is widespread, what has important functional implications. Neuronal primary cilia are believed to function as sensory organs for the cell (Pazour \& Witman 2003). The existence of primary cilia as sensory organs can be explained through an evolutionary perspective: neuronal surface components tend to interfere with the homogenization of the ECS due to electrostatic interactions between the cellular membrane and ECS proteins. An appendicular structure that projects into the ECS, distancing itself from the cellular membrane, provides an adaptive advantage by better sensing subtle changes in the extracellular matrix composition (Marshall \& Nonaka 2006). One direct inference that can be made from the fact that MCHR1 is found in the primary cilia is that MCH must be found in the ECS, outside the synaptic space, what is commonly associated with the concept of VT (Agnati et al. 1986; Agnati et al. 2010; Agnati et al. 1995).

Volume transmission concerns the communication between neurons that happens through pathways that are structurally poorly defined, occurs in a tridimensional space, and generally has multiple targets. Mechanisms of VT include the extrasynaptic spilling of neurotransmitters, release of neurochemical messengers in the ECS and CSF, and vesicle release, as 
opposed to wiring transmission, which includes synapses and gap junctions (Agnati \& Fuxe 2014; Fuxe et al. 2007). Particularly relevant for ciliary receptors is the release of neurochemical messengers in the ECS and CSF. This release can occur in several ways, including peptide vesicle release at axonal non-synaptic domains (Golding 1994), reverse-uptake release of neurotransmitters (Attwell et al. 1993), and exocytotic and non-exocytotic somatodendritic release of peptides (Pow \& Morris 1989). Once the signal is released, it can bind to receptors in the parent neurons, diffuse to neighbor neurons through the ECS, or travel to distant sites through the paravascular fluid circulation (Rennels et al. 1985), fiber bundle convection (Bjelke et al. 1995) or CSF flow.

Volume transmission mechanisms of communication have been demonstrated or suggested for a wide range of monoaminergic and peptidergic systems, including serotonin, norepinephrine, acetylcholine, dopamine, oxytocin, vasopressin, gonadotropin-releasing hormone, dynorphin, neurokinin A, substance P, cholecystokinin, enkephalin, and beta-endorphin, corticotropin-releasing factor, and orexin (Alpár et al. 2019; Agnati et al. 2010). Morphological aspects of those systems are often used as indicatives of VT, such as the presence of fiber plexuses close to the ventricle, fiber varicosities that lack synaptic specializations, somatodendritic release, and fiber-receptor mismatches. Recently, Noble et al. (2018) added MCH to the list of neuropeptides that use VT, by demonstrating that: $\mathrm{MCH}$-ir fibers contact the ventricular space; 2. Levels of MCH in the CSF fluctuate tethered to MCH neuronal activation; 3. Activation of CSF-contacting fibers modulates feeding behavior. We recently demonstrated that the intimate relationship between $\mathrm{MCH}$ fibers and the ventricular space is a common feature of muroids, suggesting some degree of phylogenetic conservation, and that not only the ventricular lumen, but the subleptomeningeal space, may be used as a vehicle for the transport of MCH (Diniz et al. 2019). Given that MCH and NEl are found in different subcellular compartments, this opens up the possibility that the two peptides may be differentially released to act on wiring and VT paradigms (Diniz et al. 2019).

It was unclear, up to this point, what are the targets of the CSF-released MCH described by Noble et al. (2018). The results obtained in our work indicate that multiple regions are equipped to respond to free $\mathrm{MCH}$, and that functions beyond the modulation of feeding behavior may be impacted. The two most likely targets for ingestive behavior modulation by free MCH are the arcuate nucleus and the paraventricular nucleus of the hypothalamus. Both structures have been thoroughly implicated in feeding behavior (Stanley \& Leibowitz 1985; Bouret et al. 2004), and injections of MCH in these areas have been shown to modulate ingestion (Abbott et al. 2003). These two areas have some of the highest densities of ciliary MCHR1 in the murine diencephalon, making them particularly apt to detect free $\mathrm{MCH}$, in particular the paraventricular nucleus due to its intimate association with the third ventricle. Although not as close the lateral ventricles as the paraventricular nucleus, numerous varicose $\mathrm{MCH}$ - and NEl-ir fibers are observed adjacent to the nucleus accumbens, suggesting MCH may be released by those fibers in the ECS and then diffuse to bind to ciliary MCHR1 in the nucleus accumbens. Although the arcuate nucleus would also be a possible target for ingestive modulation, we did not detect MCHR1 in the neurochemical populations of this area that have been related to feeding behavior.

Morphofunctional correlated indicate that several functions previously associated with MCH may be modulated through VT, in addition to the aforementioned role in feeding behavior. The widespread distribution of ciliary MCHR1 in the cortical mantle, including the motor and cingulate cortices, allows MCH to play a role in motor function (Segal-Lieberman et al. 2003) and the animal emotional state (Borowsky et al. 2002). The high density of MCHR1 in the caudate-putamen also allows MCH to act on reward circuits through the mesolimbic pathway (Domingos et al. 2013). Through the pyramidal layer of the hippocampus proper, MCH may act on learning, novelty, spatial and contextual memory retrieval, and anxiety (Sita et al. 2016; Monzon et al. 1999; Blanco-Centurion et al. 2019; Oh et al. 2019; Jimenez et al. 2018), with important ramifications for animal 
behavior. The presence of ciliary MCHR1 on dopaminergic neurons of the incerto-hypothalamic area may be the nexus for an MCH role on reproductive behavior and hormone secretion (Murray et al. 2000a), while through tuberoinfundibular dopaminergic neurons it may interface with prolactin secretion (Hökfelt \& Fuxe 1972).

The arcuate nucleus is not the only pathway through which free MCH may modulate the adenohypophyseal release of hormones. Through the preoptic periventricular nucleus, free MCH from the CSF may act on kisspeptin neurons to modulate GnRH release (Wu et al. 2009), and in the PVH it may act to modulate the function of CRF neurons. While the former is likely related to a reproductive role (Murray et al. 2000b; Murray et al. 2000c; Murray et al. 2006), the modulation of CRF neurons may be related to control of stress responses and emotion (Lagos et al. 2011; Kennedy et al. 2003; Smith et al. 2006). A modulation of sexual function may also be achieved through estrogen receptor $\alpha$ neurons of the medial preoptic area and periventricular hypothalamus. The presence of MCHR1 in the medial preoptic area may also be important for the display of maternal behavior (Alachkar et al. 2016; Benedetto et al. 2014), if the lactation-generated MCH neurons of the medial preoptic area (Knollema et al. 1992; Rondini et al. 2010; Alvisi et al. 2016; Costa et al. 2019; Ferreira et al. 2017b) release MCH in a paracrine mode. Finally, another major function that may be played by MCH through VT is olfactory integration. One of the densest areas of ciliary MCHR1 is the olfactory bulb, where MCHR1 is found in several key layers, in addition to other ancillary areas important for olfactory processing, including the piriform cortex, anterior olfactory nucleus, olfactory tubercle, and taenia tecta. The presence of MCHR1 in two very important populations of the glomerular layer, dopamine and calbindin cells, in particular, indicates that those cells are the way through which MCH acts on olfactory integration, a role previously suggested for MCH (Adams et al. 2011; Alhassen et al. 2019).

In conclusion, we mapped for the first time the distribution of ciliary MCHR1 immunoreactivity in the brain of rats and mice. To do that, we evaluated a panel of commercial antibodies and identified one that has high specificity, good signal/background ratio, and that identifies an epitope that has been well conserved among mammals. The identification of immunoreactivity is a powerful tool, for it correlates with actual receptor production by the cells, giving us the closest functional readout of $\mathrm{MCH}$ action sites possible. All immunoreactivity detected with this antibody is ciliary, given the colocalization between MCHR1 and a specific neuronal primary cilium marker in all areas examined. Given the role of the neuronal primary cilia in sensing of the extracellular space, this colocalization suggests MCH can be found outside the synaptic space, and that free MCH may have an important role in VT modes of neuromodulatory signaling. Given the widespread distribution of ciliary MCHR1, it is fundamental that further studies are conducted to better understand how volume transmission affects the MCH system, what may open the possibility to new venues of pharmacological intervention targeting MCHR1 in the future.

\section{References}

Abbott, C. R., Kennedy, A. R., Wren, A. M. et al. (2003) Identification of hypothalamic nuclei involved in the orexigenic effect of melanin-concentrating hormone. Endocrinology 144, 3943-3949.

Adamantidis, A., Thomas, E., Foidart, A. et al. (2005) Disrupting the melanin-concentrating hormone receptor 1 in mice leads to cognitive deficits and alterations of NMDA receptor function. European journal of neuroscience 21, 2837-2844.

Adams, A. C., Domouzoglou, E. M., Chee, M. J., Segal-Lieberman, G., Pissios, P. and Maratos-Flier, E. (2011) Ablation of the hypothalamic neuropeptide melanin concentrating hormone is associated with behavioral abnormalities that reflect impaired olfactory integration. Behavioural Brain Research 224, 195-200.

Agnati, L. F. and Fuxe, K. (2014) Extracellular-vesicle type of volume transmission and tunnelling-nanotube type of wiring transmission add a new dimension to brain neuro-glial networks. Philosophical Transactions of the Royal Society B: Biological Sciences 369, 1-13. 
Agnati, L. F., Fuxe, K., Zoli, M., Zini, I., Toffano, G. and Ferraguti, F. (1986) A correlation analysis of the regional distribution of central enkephalin and $\beta$-endorphin immunoreactive terminals and of opiate receptors in adult and old male rats. Evidence for the existence of two main types of communication in the central nervous system: the volume transmission and the wiring transmission. Acta Physiologica Scandinavica 128, 201-207.

Agnati, L. F., Guidolin, D., Guescini, M., Genedani, S. and Fuxe, K. (2010) Understanding wiring and volume transmission. Brain research reviews 64, 137-159.

Agnati, L. F., Zoli, M., Strömberg, I. and Fuxe, K. (1995) Intercellular communication in the brain: wiring versus volume transmission. Neuroscience 69, 711-726.

Alachkar, A., Alhassen, L., Wang, Z., Wang, L., Onouye, K., Sanathara, N. and Civelli, O. (2016) Inactivation of the melanin concentrating hormone system impairs maternal behavior. European Neuropsychopharmacology 26, 1826-1835.

Alhassen, L., Phan, A., Alhassen, W., Nguyen, P., Lo, A., Shaharuddin, H., Sanathara, N., Civelli, O. and Alachkar, A. (2019) The role of Olfaction in MCH-regulated spontaneous maternal responses. Brain research 1719, 7176.

Alpár, A., Benevento, M., Romanov, R. A., Hökfelt, T. and Harkany, T. (2019) Hypothalamic cell diversity: nonneuronal codes for long-distance volume transmission by neuropeptides. Current opinion in neurobiology 56, 16-23.

Alvisi, R. D., Diniz, G. B., Da-Silva, J. M., Bittencourt, J. C. and Felicio, L. F. (2016) Suckling-induced Fos activation and melanin-concentrating hormone immunoreactivity during late lactation. Life sciences 148, 241-246.

Attwell, D., Barbour, B. and Szatkowski, M. (1993) Nonvesicular release of neurotransmitter. Neuron 11, 401-407.

Bächner, D., Kreienkamp, H.-J., Weise, C., Buck, F. and Richter, D. (1999) Identification of melanin concentrating hormone $(\mathrm{MCH})$ as the natural ligand for the orphan somatostatin-like receptor 1 (SLC-1). FEBS letters 457, 522-524.

Benedetto, L., Pereira, M., Ferreira, A. and Torterolo, P. (2014) Melanin-concentrating hormone in the medial preoptic area reduces active components of maternal behavior in rats. Peptides 58, 20-25.

Berbari, N. F., Johnson, A. D., Lewis, J. S., Askwith, C. C. and Mykytyn, K. (2008) Identification of ciliary localization sequences within the third intracellular loop of $\mathrm{G}$ protein-coupled receptors. Molecular Biology of the Cell 19, 1540-1547.

Berbari, N. F., O'Connor, A. K., Haycraft, C. J. and Yoder, B. K. (2009) The primary cilium as a complex signaling center. Current Biology 19, R526-R535.

Bishop, G. A., Berbari, N. F., Lewis, J. and Mykytyn, K. (2007) Type III adenylyl cyclase localizes to primary cilia throughout the adult mouse brain. Journal of Comparative Neurology 505, 562-571.

Bittencourt, J. C. and Celis, M. E. (2008) Anatomy, function and regulation of neuropeptide El (NEI). Peptides 29, 1441-1450.

Bittencourt, J. C. and Diniz, G. B. (2018) Neuroanatomical Structure of the MCH System. In: Melanin-Concentrating Hormone and Sleep, pp. 1-46. Springer.

Bittencourt, J. C., Presse, F., Arias, C., Peto, C. A., Vaughan, J. M., Nahon, J.-L., Vale, W. and Sawchenko, P. E. (1992) The melanin-concentrating hormone system of the rat brain: an immuno- and hybridization histochemical characterization. The Jorunal of Comparative Neurology 319, 218-245.

Bjelke, B., England, R., Nicholson, C., Rice, M. E., Lindberg, J., Zoli, M., Agnati, L. F. and Fuxe, K. (1995) Long distance pathways of diffusion for dextran along fibre bundles in brain. Relevance for volume transmission. Neuroreport 6, 1005-1009.

Blanco-Centurion, C., Luo, S., Spergel, D. J., Vidal-Ortiz, A., Oprisan, S. A., Van den Pol, A. N., Liu, M. and Shiromani, P. J. (2019) Dynamic Network Activation of Hypothalamic MCH Neurons in REM Sleep and Exploratory Behavior. Journal of Neuroscience 39, 4986-4998.

Borowsky, B., Durkin, M. M., Ogozalek, K. et al. (2002) Antidepressant, anxiolytic and anorectic effects of a melanin-concentrating hormone-1 receptor antagonist. Nature medicine 8, 825 . 
Bouret, S. G., Draper, S. J. and Simerly, R. B. (2004) Formation of projection pathways from the arcuate nucleus of the hypothalamus to hypothalamic regions implicated in the neural control of feeding behavior in mice. Journal of Neuroscience 24, 2797-2805.

Brailov, I., Bancila, M., Brisorgueil, M.-J., Miquel, M.-C., Hamon, M. and Vergé, D. (2000) Localization of 5-HT6 receptors at the plasma membrane of neuronal cilia in the rat brain. Brain research 872, 271-275.

Breunig, J. J., Sarkisian, M. R., Arellano, J. I. et al. (2008) Primary cilia regulate hippocampal neurogenesis by mediating sonic hedgehog signaling. PNAS 105, 13127-13132.

Brown, S. N., Chitravanshi, V. C., Kawabe, K. and Sapru, H. N. (2007) Microinjections of melanin concentrating hormone into the nucleus tractus solitarius of the rat elicit depressor and bradycardic responses. Neuroscience 150, 796-806.

Byers, S. L., Wiles, M. V., Dunn, S. L. and Taft, R. A. (2012) Mouse estrous cycle identification tool and images. PloS one 7, e35538.

Chambers, J., Ames, R. S., Bergsma, D. et al. (1999) Melanin-concentrating hormone is the cognate ligand for the orphan G-protein-coupled receptor SLC-1. Nature 400, 261-265.

Chee, M. J., Hebert, A. J., Briançon, N., Flaherty III, S. E., Pissios, P. and Maratos-Flier, E. (2019) Conditional deletion of melanin-concentrating hormone receptor 1 from GABAergic neurons increases locomotor activity. Molecular Metabolism.

Chee, M. J. S., Pissios, P. and Maratos-Flier, E. (2013) Neurochemical characterization of neurons expressing melanin-concentrating hormone receptor 1 in the mouse hypothalamus. Journal of Comparative Neurology 521, 2208-2234.

Chiocchio, S. R., Gallardo, M. a. G. P., Louzan, P., Gutnisky, V. and Tramezzani, J. H. (2001) Melanin-concentrating hormone stimulates the release of luteinizing hormone-releasing hormone and gonadotropins in the female rat acting at both median eminence and pituitary levels. Biology of Reproduction 64, 1466-1472.

Conductier, G., Brau, F., Viola, A. et al. (2013a) Melanin-concentrating hormone regulates beat frequency of ependymal cilia and ventricular volume. Nature neuroscience 16, 845-847.

Conductier, G., Martin, A. O., Risold, P.-Y., Jego, S., Lavoie, R., Lafont, C., Mollard, P., Adamantidis, A. and Nahon, J.-L. (2013b) Control of ventricular ciliary beating by the melanin concentrating hormone-expressing neurons of the lateral hypothalamus: a functional imaging survey. Frontiers in Endocrinology 4, 1-9.

Corbit, K. C., Aanstad, P., Singla, V., Norman, A. R., Stainier, D. Y. R. and Reiter, J. F. (2005) Vertebrate Smoothened functions at the primary cilium. Nature 437, 1018.

Costa, H. C., Da-Silva, J. M., Diniz, G. B. et al. (2019) Characterization and origins of melanin-concentrating hormone immunoreactive fibers of the posterior lobe of the pituitary and median eminence during lactation in Long-Evans rat. Journal of Neuroendocrinology 00:e12723.

Diniz, G. B., Battagello, D. S., Cherubini, P. M. et al. (2019) Melanin-concentrating hormone peptidergic system: comparative morphology between muroid species. Journal of Comparative Neurology In press

Diniz, G. B. and Bittencourt, J. C. (2017) The Melanin-Concentrating Hormone as an Integrative Peptide Driving Motivated Behaviors. Frontiers in Systems Neuroscience 11, 1-32.

Domingos, A. I., Sordillo, A., Dietrich, M. O. et al. (2013) Hypothalamic melanin concentrating hormone neurons communicate the nutrient value of sugar. eLife 2, e01462.

Engle, S. E., Antonellis, P. J., Whitehouse, L. S., Bansal, R., Emond, M. R., Jontes, J. D., Kesterson, R. A., Mykytyn, K. and Berbari, N. F. (2018) A CreER mouse to study melanin concentrating hormone signaling in the developing brain. genesis 56, e23217.

Eriksson, P. S., Perfilieva, E., Björk-Eriksson, T., Alborn, A.-M., Nordborg, C., Peterson, D. A. and Gage, F. H. (1998) Neurogenesis in the adult human hippocampus. Nature medicine 4, 1313.

Ferreira, J. G. P., Bittencourt, J. C. and Adamantidis, A. (2017a) Melanin-concentrating hormone and sleep. Current Opinion in Neurobiology 44, 152-158. 
Ferreira, J. G. P., Duarte, J. C. G., Diniz, G. B. and Bittencourt, J. C. (2017b) Litter size determines the number of melanin-concentrating hormone neurons in the medial preoptic area of Sprague Dawley lactating dams. Physiology \& Behavior 181, 75-79.

Fuxe, K., Dahlström, A., Höistad, M. et al. (2007) From the Golgi-Cajal mapping to the transmitter-based characterization of the neuronal networks leading to two modes of brain communication: wiring and volume transmission. Brain Research Reviews 55, 17-54.

Gao, X.-B. (2018) The Role of Melanin-Concentrating Hormone in the Regulation of the Sleep/Wake Cycle: Sleep Promoter or Arousal Modulator? In: Melanin-Concentrating Hormone and Sleep : Molecular, Functional and Clinical Aspects, (S. R. Pandi-Perumal, P. Torterolo and J. M. Monti eds.), pp. 57-74. Springer International Publishing, Cham.

Golding, D. W. (1994) A pattern confirmed and refined-synaptic, nonsynaptic and parasynaptic exocytosis. Bioessays 16, 503-508.

Gonzalez, M. I., Vaziri, S. and Wilson, C. A. (1996) Behavioral effects of alpha-MSH and MCH after central administration in the female rat. Peptides 17, 171-177.

Händel, M., Schulz, S., Stanarius, A., Schreff, M., Erdtmann-Vourliotis, M., Schmidt, H., Wolf, G. L. and Höllt, V. (1999) Selective targeting of somatostatin receptor 3 to neuronal cilia. Neuroscience 89, 909-926.

Hervieu, G., Cluderay, J., Harrison, D., Meakin, J., Maycox, P., Nasir, S. and Leslie, R. A. (2000) The distribution of the mRNA and protein products of the melanin-concentrating hormone $(\mathrm{MCH})$ receptor gene, slc-1, in the central nervous system of the rat. European Journal of Neuroscience 12, 1194-1216.

Hoffman, G. E., Murphy, K. J. and Sita, L. V. (2016) The importance of titrating antibodies for immunocytochemical methods. Current Protocols in Neuroscience 76, 2.12.11-12.12.37.

Hökfelt, T. and Fuxe, K. (1972) Effects of prolactin and ergot alkaloids on the tubero-infundibular dopamine (DA) neurons. Neuroendocrinology 9, 100-122.

Jiang, H. and Brüning, J. C. (2018) Melanin-Concentrating Hormone-Dependent Control of Feeding: When Volume Matters. Cell Metabolism 28, 7-8.

Jimenez, J. C., Su, K., Goldberg, A. R. et al. (2018) Anxiety cells in a hippocampal-hypothalamic circuit. Neuron 97, 670-683. e676.

Kennedy, A. R., Todd, J. F., Dhillo, W. S. et al. (2003) Effect of direct injection of melanin-concentrating hormone into the paraventricular nucleus: further evidence for a stimulatory role in the adrenal axis via SLC-1. Journal of Neuroendocrinology 15, 268-272.

Knollema, S., Brown, E. R., Vale, W. and Sawchenko, P. E. (1992) Novel hypothalamic and preoptic sites of prepromelanin-concentrating hormone messenger ribonucleic Acid and Peptide expression in lactating rats. Journal of Neuroendocrinology 4, 709-717.

Koemeter-Cox, A. I., Sherwood, T. W., Green, J. A. et al. (2014) Primary cilia enhance kisspeptin receptor signaling on gonadotropin-releasing hormone neurons. PNAS, 201403286.

Kummer, K. K., Hofhansel, L., Barwitz, C. M., Schardl, A., Prast, J. M., Salti, A., El Rawas, R. and Zernig, G. (2014) Differences in social interaction-vs. cocaine reward in mouse vs. rat. Frontiers in behavioral neuroscience 8, 363.

Lagos, P., Urbanavicius, J., Scorza, M. C., Miraballes, R. and Torterolo, P. (2011) Depressive-like profile induced by $\mathrm{MCH}$ microinjections into the dorsal raphe nucleus evaluated in the forced swim test. Behavioural brain research 218, 259-266.

Loktev, A. V. and Jackson, P. K. (2013) Neuropeptide Y family receptors traffic via the Bardet-Biedl syndrome pathway to signal in neuronal primary cilia. Cell Reports 5, 1316-1329.

Mandl, L. and Megele, R. (1989) Primary cilia in normal human neocortical neurons. Zeitschrift fur mikroskopischanatomische Forschung 103, 425-430.

Marshall, W. F. and Nonaka, S. (2006) Cilia: tuning in to the cell's antenna. Current Biology 16, R604-R614.

Messina, M. M. and Overton, J. M. (2007) Cardiovascular effects of melanin-concentrating hormone. Regulatory Peptides 139, 23-30. 
Monzon, M. E., de Souza, M. M., Izquierdo, L. A., Izquierdo, I., Barros, D. M. and de Barioglio, S. R. (1999) Melaninconcentrating hormone $(\mathrm{MCH})$ modifies memory retention in rats. Peptides 20, 1517-1519.

Murray, J., Mercer, J., Adan, R., Datta, J., Aldairy, C., Moar, K., Baker, B., Stock, M. and Wilson, C. (2000a) The effect of leptin on luteinizing hormone release is exerted in the zona incerta and mediated by melaninconcentrating hormone. Journal of neuroendocrinology 12, 1133-1139.

Murray, J. F., Adan, R. A. H., Walker, R., Baker, B. I., Thody, A. J., Nijenhuis, W. A., Yukitake, J. and Wilson, C. A. (2000b) Melanin-concentrating hormone, melanocortin receptors and regulation of luteinizing hormone release. Journal of Neuroendocrinology 12, 217-223.

Murray, J. F., Baker, B. I., Levy, A. and Wilson, C. A. (2000c) The influence of gonadal steroids on pre-pro melaninconcentrating hormone mRNA in female rats. Journal of Neuroendocrinology 12, 53-59.

Murray, J. F., Hahn, J. D., Kennedy, A. R., Small, C. J., Bloom, S. R., Haskell-Luevano, C., Coen, C. W. and Wilson, C. A. (2006) Evidence for a Stimulatory Action of Melanin-Concentrating Hormone on Luteinising Hormone Release Involving MCH1 and Melanocortin-5 Receptors. Journal of Neuroendocrinology 18, 157-167.

Naufahu, J., Cunliffe, A. D. and Murray, J. F. (2013) The roles of melanin-concentrating hormone in energy balance and reproductive function: are they connected? Reproduction 146, R141-R150.

Niño-Rivero, S., Torterolo, P. and Lagos, P. (2019) Melanin-concentrating hormone receptor-1 is located in primary cilia of the dorsal raphe neurons. Journal of chemical neuroanatomy 98, 55-62.

Noble, E. E., Hahn, J. D., Konanur, V. R. et al. (2018) Control of Feeding Behavior by Cerebral Ventricular Volume Transmission of Melanin-Concentrating Hormone. Cell metabolism 28, 55-68.e57.

Oh, S. T., Liu, Q. F., Jeong, H. J. et al. (2019) Nasal Cavity Administration of Melanin-Concentrating Hormone Improves Memory Impairment in Memory-Impaired and Alzheimer's Disease Mouse Models. Molecular Neurobiology.

Paxinos, G. and Franklin, K. (2012) The Mouse Brain in Stereotaxic Coordinates. Academic Press.

Paxinos, G. and Watson, C. (2006) The rat brain in stereotaxic coordinates: hard cover edition. Elsevier.

Pazour, G. J. and Witman, G. B. (2003) The vertebrate primary cilium is a sensory organelle. Current Opinion in Cell Biology 15, 105-110.

Pow, D. and Morris, J. (1989) Dendrites of hypothalamic magnocellular neurons release neurohypophysial peptides by exocytosis. Neuroscience 32, 435-439.

Presse, F., Conductier, G., Rovere, C. and Nahon, J. (2014) The melanin-concentrating hormone receptors: neuronal and non-neuronal functions. International journal of obesity supplements $\mathbf{4}$, S31.

Qu, D., Ludwig, D. S., Gammeltoft, S. et al. (1996) A role for melanin-concentrating hormone in the central regulation of feeding behaviour. Nature 380, 243-247.

Rennels, M. L., Gregory, T. F., Blaumanis, O. R., Fujimoto, K. and Grady, P. A. (1985) Evidence for a 'paravascular' fluid circulation in the mammalian central nervous system, provided by the rapid distribution of tracer protein throughout the brain from the subarachnoid space. Brain Res 326, 47-63.

Rohatgi, R., Milenkovic, L. and Scott, M. P. (2007) Patched1 regulates hedgehog signaling at the primary cilium. Science 317, 372-376.

Rondini, T. A., Donato, J., Rodrigues, B. C., Bittencourt, J. C. and Elias, C. F. (2010) Chemical identity and connections of medial preoptic area neurons expressing melanin-concentrating hormone during lactation. Journal of chemical neuroanatomy 39, 51-62.

Saito, Y., Cheng, M., Leslie, F. M. and Civelli, O. (2001) Expression of the melanin-concentrating hormone (MCH) receptor mRNA in the rat brain. Journal of Comparative Neurology 435, 26-40.

Saito, Y., Nothacker, H.-P., Wang, Z., Lin, S. H. S., Leslie, F. and Civelli, O. (1999) Molecular characterization of the melanin-concentrating-hormone receptor. Nature 400, 265-269.

Saper, C. B. and Sawchenko, P. E. (2003) Magic peptides, magic antibodies: guidelines for appropriate controls for immunohistochemistry. Journal of Comparative Neurology 465, 161-163.

Segal-Lieberman, G., Bradley, R. L., Kokkotou, E. et al. (2003) Melanin-concentrating hormone is a critical mediator of the leptin-deficient phenotype. Proceedings of the National Academy of Sciences 100, 10085-10090. 
Shimomura, Y., Mori, M., Sugo, T. et al. (1999) Isolation and identification of melanin-concentrating hormone as the endogenous ligand of the SLC-1 receptor. Biochemical and Biophysical Research Communications 261, 622-626.

Siljee, J. E., Wang, Y., Bernard, A. A., Ersoy, B. A., Zhang, S., Marley, A., Von Zastrow, M., Reiter, J. F. and Vaisse, C. (2018) Subcellular localization of MC4R with ADCY3 at neuronal primary cilia underlies a common pathway for genetic predisposition to obesity. Nature Genetics 50, 180-185.

Sita, L. V., Diniz, G. B., Canteras, N. S., Xavier, G. F. and Bittencourt, J. C. (2016) Effect of intrahippocampal administration of anti-melanin-concentrating hormone on spatial food-seeking behavior in rats. Peptides 76, 130-138.

Smith, D. G., Davis, R. J., Rorick-Kehn, L., Morin, M., Witkin, J. M., McKinzie, D. L., Nomikos, G. G. and Gehlert, D. R. (2006) Melanin-concentrating hormone-1 receptor modulates neuroendocrine, behavioral, and corticolimbic neurochemical stress responses in mice. Neuropsychopharmacology 31, 1135-1145.

Snyder, J. S., Choe, J. S., Clifford, M. A., Jeurling, S. I., Hurley, P., Brown, A., Kamhi, J. F. and Cameron, H. A. (2009) Adult-born hippocampal neurons are more numerous, faster maturing, and more involved in behavior in rats than in mice. Journal of Neuroscience 29, 14484-14495.

Stanley, B. G. and Leibowitz, S. F. (1985) Neuropeptide Y injected in the paraventricular hypothalamus: a powerful stimulant of feeding behavior. Proceedings of the National Academy of Sciences 82, 3940-3943.

Tan, C. P., Sano, H., Iwaasa, H. et al. (2002) Melanin-concentrating hormone receptor subtypes 1 and 2: speciesspecific gene expression. Genomics 79, 785-792.

Wu, M., Dumalska, I., Morozova, E., van den Pol, A. N. and Alreja, M. (2009) Melanin-concentrating hormone directly inhibits $\mathrm{GnRH}$ neurons and blocks kisspeptin activation, linking energy balance to reproduction. Proceedings of the National Academy of Sciences 106, 17217-17222. 
bioRxiv preprint doi: https://doi.org/10.1101/755967; this version posted September 8, 2019. The copyright holder for this preprint (which was not certified by peer review) is the author/funder, who has granted bioRxiv a license to display the preprint in perpetuity. It is made available under aCC-BY-NC 4.0 International license.

Diniz et al, 2019

Ciliary MCHR1 in murines

\section{Tables}

Table 1. Primary antibodies employed in this work

\begin{tabular}{|c|c|c|c|c|c|c|c|}
\hline Antiboby & Manufacturer & Man. ID & RRID & Antiboby & Manufacturer & Man. ID & RRID \\
\hline $\begin{array}{l}\text { Rabbit anti melanin- } \\
\text { concentrating hormone } \\
\text { receptor } 1 \text { (anti- } \\
\text { hMCHR1) }\end{array}$ & $\begin{array}{l}\text { ThermoFisher } \\
\text { Scientific }\end{array}$ & PA5-24182 & AB_2541682 & $\begin{array}{l}\text { Rabbit gonadotropin- } \\
\text { releasing hormone (anti- } \\
\text { GnRH) }\end{array}$ & ImmunoStar & 20075 & AB_572248 \\
\hline $\begin{array}{l}\text { Rabbit anti melanin- } \\
\text { concentrating hormone } \\
\text { receptor } 1 \text { (anti- } \\
\text { hMCHR1) }\end{array}$ & Abcam & Ab97509 & AB_10680290 & $\begin{array}{l}\text { Rabbit anti kisspeptin (anti- } \\
\text { KiSS) }\end{array}$ & $\begin{array}{l}\text { Millipore } \\
\text { (Chemicon) }\end{array}$ & AB9754 & AB_2296529 \\
\hline $\begin{array}{l}\text { Rabbit anti melanin- } \\
\text { concentrating hormone } \\
\text { receptor } 1 \text { (anti- } \\
\text { hMCHR1) }\end{array}$ & $\begin{array}{c}\text { SantaCruz } \\
\text { Biotechnology }\end{array}$ & sc- 25667 & AB_2143948 & $\begin{array}{l}\text { Rabbit anti estrogen } \\
\text { receptor a (anti-ERa) }\end{array}$ & Millipore (Upstate) & 06-935 & AB_310305 \\
\hline $\begin{array}{l}\text { Rabbit anti melanin- } \\
\text { concentrating hormone } \\
\text { receptor } 1 \text { (anti- } \\
\text { hMCHR1) }\end{array}$ & $\begin{array}{c}\text { SantaCruz } \\
\text { Biotechnology }\end{array}$ & Sc-5534 & AB_2143957 & $\begin{array}{l}\text { Rabbit anti vasopressin } \\
\text { (anti-AVP) }\end{array}$ & $\begin{array}{l}\text { ImmunoStar } \\
\text { (DiaSorin) }\end{array}$ & 20069 & AB_572219 \\
\hline $\begin{array}{l}\text { Rabbit anti melanin- } \\
\text { concentrating hormone } \\
\text { receptor } 1 \text { (anti- } \\
\text { hMCHR1) }\end{array}$ & $\begin{array}{l}\text { Sigma- } \\
\text { Aldrich/Atlas }\end{array}$ & HPA004149 & AB_1079363 & $\begin{array}{l}\text { Guinea-pig anti oxytocin } \\
\text { (anti-OT) }\end{array}$ & Peninsula & $\begin{array}{c}\mathrm{T}- \\
5021.0050\end{array}$ & AB_518526 \\
\hline $\begin{array}{l}\text { Rabbit anti melanin- } \\
\text { concentrating hormone } \\
\text { receptor } 1 \text { (anti-rMCHR1) }\end{array}$ & Alomone Labs & AMR-041 & AB_11218957 & $\begin{array}{l}\text { Rabbit anti corticotropin- } \\
\text { releasing factor (anti-CRF) }\end{array}$ & $\begin{array}{l}\text { Peptide Biology } \\
\text { Laboratory, The } \\
\text { Salk Institute }\end{array}$ & rC70 & AB_2650437 \\
\hline $\begin{array}{l}\text { Rabbit anti adenylate } \\
\text { cyclase III (anti-AC3) }\end{array}$ & $\begin{array}{l}\text { ThermoFisher } \\
\text { Scientific }\end{array}$ & PA5-35382 & AB_2552692 & $\begin{array}{l}\text { Sheep anti a -melanocyte- } \\
\text { stimulating hormone (anti- } \\
\text { a MSH) }\end{array}$ & $\begin{array}{l}\text { Millipore } \\
\text { (Chemicon) }\end{array}$ & AB5087 & AB_91683 \\
\hline $\begin{array}{l}\text { Rabbit anti melanin- } \\
\text { concentrating hormone } \\
\text { (anti-MCH) }\end{array}$ & $\begin{array}{l}\text { Peptide Biology } \\
\text { Laboratory, The } \\
\text { Salk Institute }\end{array}$ & PBL \#234 & AB_2650444 & $\begin{array}{l}\text { Rabbit anti cocaine- and } \\
\text { amphetamine-regulated } \\
\text { transcript (anti-CART) }\end{array}$ & $\begin{array}{l}\text { Peptide Biology } \\
\text { Laboratory, The } \\
\text { Salk Institute }\end{array}$ & 6838 & AB_2650446 \\
\hline $\begin{array}{l}\text { Mouse anti tyrosine } \\
\text { hydroxylase (anti-TH) }\end{array}$ & ImmunoStar & \#22941 & AB_572268 & $\begin{array}{l}\text { Mouse anti neuron-specific } \\
\text { nuclear protein (anti- } \\
\text { NeuN) }\end{array}$ & $\begin{array}{l}\text { Millipore } \\
\text { (Chemicon) }\end{array}$ & MAB377 & AB_2298772 \\
\hline $\begin{array}{l}\text { Mouse anti calbindin D- } \\
28 \mathrm{k}\end{array}$ & Swant & 300 & AB_10000347 & $\begin{array}{l}\text { Mouse anti glial fibrillary } \\
\text { acidic protein (anti-GFAP) }\end{array}$ & Sigma-Aldrich & G3893 & AB_477010 \\
\hline $\begin{array}{l}\text { Goat anti (rat, mouse, } \\
\text { human) calretinin }\end{array}$ & Swant & CG1 & AB_10000342 & $\begin{array}{l}\text { Mouse anti doublecortin } \\
\quad(\text { anti-DCX) }\end{array}$ & Santa Cruz & Sc-8066 & AB_2088494 \\
\hline
\end{tabular}


Table 2. Relative density of MCHR1-ir cilia in the mouse CNS

\section{Cell group}

\section{A. Olfactory areas}

\section{Main olfactory bulb}

Glomerular layer

Juxtaglomerular layer

External plexiform layer

Mitral layer

Internal plexiform layer

Granule cells layer

External part

Internal part

\section{Accessory olfactory bulb}

Accessory granule cells layer

Accessory mitral layer

Accessory external plexiform layer

3. Anterior olfactory nucleus

$$
\begin{aligned}
& \text { Medial part } \\
& \text { Dorsal part } \\
& \text { Lateral part } \\
& \text { Ventral part } \\
& \text { External part }
\end{aligned}
$$

\section{Olfactory Cortex}

Ventral tenia tecta

$$
\text { Layer } 1
$$

Layer 3

Dorsal tenia tecta

$$
\begin{aligned}
& \text { Layer } 1 \\
& \text { Layer } 2 \\
& \text { Layer } 3
\end{aligned}
$$

Piriform cortex

$$
\begin{aligned}
& \text { Layer } 1 \\
& \text { Layer } 2
\end{aligned}
$$$$
\text { Layer } 3
$$

Endopiriform nucleus

$$
\text { Dorsal part }
$$$$
\text { Internal part }
$$

Olfactory tubercle

$$
\begin{aligned}
& \text { Layer } 1 \\
& \text { Layer } 2 \\
& \text { Layer } 3
\end{aligned}
$$

\section{MCHR1-ir cilia}

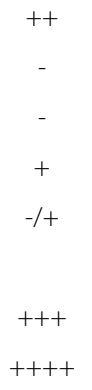

$+++$

$-$

$$
-
$$

$+$

$++$

$++$

$++$

$$
-
$$$$
++
$$$$
-/+
$$

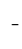

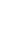

Cell group

B. Septofimbrial area

1. Septal nucleus

Lateral septal nucleus

Ventral part

$++$

Dorsal part

Intermediate part

Medial septal nucleus

Medial column

Lateral column

Lambdoid Septal Zone

2. Diagonal band of Broca

Vertical limb

Horizontal limb

3. Transitional nuclei

Septohippocampal nucleus

Septofimbrial nucleus

Septohypothalamic nucleus

\section{Bed nucleus of the stria terminalis}

Rostromedial region

Rostrolateral region

Posteromedial region

Posterolateral region

\section{Indusium griseum}

6. Islands of Calleja

7. Triangular septal nucleus

8. Bed nucleus of the anterior commissure

\section{Basal nuclei and associated structures}

1. Caudate-putamen nucleus

Matrix

$$
\begin{aligned}
& \text { Medial part } \\
& \text { Lateral part }
\end{aligned}
$$$$
++++
$$

$$
+++
$$

Striosomes

\section{Nucleus accumbens}

$\begin{array}{ll}\text { Core part } & ++++ \\ \text { Shell part } & ++++ \\ \text { Lateral accumbens (fundus of striatum) } & +++\end{array}$

3. Ventral pallidum

$++$
4. Globus pallidus

5. Subthalamic nucleus 
bioRxiv preprint doi: https://doi.org/10.1101/755967; this version posted September 8, 2019. The copyright holder for this preprint (which was not certified by peer review) is the author/funder, who has granted bioRxiv a license to display the preprint in perpetuity. It is made available under aCC-BY-NC 4.0 International license.

Table 2. Relative density of MCHR1-ir cilia in the mouse CNS, continued

\section{Cell group}

D. Cortical mantle
Layer I
Layer II
Layer III
Layer IV
Layer V
Layer VI
Claustrum
Anterior
Posterior

\section{E. Hippocampal formation}

1. Fasciola Cinerea

\section{Hippocampus proper}

CA1

\section{Stratum oriens}

Stratum pyramidale

Stratum radiatum

Stratum lacunosum-moleculare

CA2

Stratum oriens

Stratum pyramidale

CA3

Stratum oriens

Stratum pyramidale

Stratum radiatum

Stratum lacunosum-moleculare

\section{Dentate gyrus}

$$
\begin{aligned}
& \text { Polymorphic layer } \\
& \text { Granule cells layer } \\
& \text { Subgranular zone } \\
& \text { Molecular layer }
\end{aligned}
$$

\section{Subiculum}

Dorsal part

Ventral part

\section{F. Amygdaloid complex}

1. Cortex-amygdala transition zone

Layer 1

Layer 2

Layer 3
MCHR1-ir cilia

-
++
$-/+$
-
+
+
$-/+$
+

$++++$

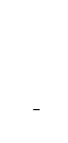

$+++$

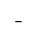

$-$

-
-
++
+
+
-

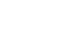

-
-
-
-
++
+++

\section{Cell group}

2. Nucleus of the lateral olivary tract

\section{Anterior division}

Anterior cortical amygdaloid nucleus

Anterior amygdaloid nucleus

Extension of the amygdala

4. Intercalated nucleus of the

\section{amygdala}

5. Basolateral division

Anterior basolateral nucleus

Ventral basolateral nucleus

\section{Central nucleus}

$$
\begin{aligned}
& \text { Central part } \\
& \text { Medial part } \\
& \text { Lateral part }
\end{aligned}
$$

\section{Medial division}

Anterodorsal medial nucleus

Anteroventral medial nucleus $\quad-/+$

Posterodorsal medial nucleus +

Posteroventral medial nucleus

\section{Basomedial division}

Posterior basomedial nucleus

Anterior basomedial nucleus

\section{G. Hypothalamus}

\section{Periventricular zone}

Anteroventral periventricular nucleus +

Median preoptic nucleus

Preoptic periventricular nucleus

$$
\text { Dorsal part }
$$

Ventral part

Suprachiasmatic nucleus

Paraventricular hypothalamic nucleus

$\begin{array}{lc}\text { Anterior parvicellular part } & + \\ \text { Medial parvicellular part } & + \\ \text { Medial magnocellular part } & +++ \\ \text { Ventral part } & +++ \\ \text { Lateral magnocellular part } & +++ \\ \text { Subparaventricular area } & -/+ \\ \text { Posterior part } & + \\ \text { Arcuate nucleus } & \\ \text { Anterior } & + \\ \text { Intermediate } & ++\end{array}$


Table 2. Relative density of MCHR1-ir cilia in the mouse CNS, continued

\section{Cell group}

2. Medial zone

Ventromedial preoptic nucleus

Medial preoptic area

Medial preoptic nucleus

Medial part

Lateral part

Anterior hypothalamic nucleus

Anterior part

Central part

Posterior part

Retrochiasmatic area

Incerto-hypothalamic area

Subincertal nucleus

Ventromedial hypothalamic nucleus

Dorsomedial hypothalamic nucleus

Posterior hypothalamic area

Dorsal tuberomammilary nucleus

Premammillary nucleus

Dorsal part

Ventral part

Retromammillary nucleus

Median mammillary nucleus

Medial mammillary nucleus

Medial part

Lateral part

Lateral mammillary nucleus

\section{Lateral zone}

Lateral preoptic area

Ventrolateral preoptic nucleus

Lateral hypothalamic area

Anterior level

Tuberal level

\section{H. Thalamus}

1. Medial habenula

$$
\text { Dorsal part }
$$

Ventral part

2. Lateral habenula

3. Anterior group

Anteromedial thalamic nucleus

Anteroventral thalamic nucleus

MCHR1-ir cilia

$+$

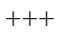

$-/+$

$-/+$

$-/+$

\section{Cell group}

Anterodorsal thalamic nucleus

Interoanteromedial thalamic nucleus

Interoanterodorsal thalamic nucleus

\section{Mediodorsal nucleus}

MD

MDM

\section{Laterodorsal nucleus}

Dorsomedial part

Ventrolateral part

\section{Midline group}

Paraventricular thalamic nucleus

Paratenial thalamic nucleus

Nucleus reuniens

Xifoid nucleus

Rhomboid nucleus

Intermediodorsal thalamic nucleus

7. Intralaminar nuclei

Paracentral thalamic nucleus

Centromedial thalamic nucleus

Centrolateral thalamic nucleus

Parafascicular thalamic nucleus

\section{Ventral group}

Ventrolateral thalamic nucleus

Ventromedial thalamic nucleus

$-/+$

Ventral posterolateral thalamic nucleus

Ventral posteromedial thalamic nucleus

\section{Posterior complex}

10. Medial geniculate

11. Lateral geniculate

\section{Reticular nucleus}

Subparafascicular thalamic nucleus

Parasubthalamic nucleus

\section{Circumventricular organs}

1. Vascular organ of the lamina terminalis

\section{MCHR1-ir cilia}

$-/+$

$-/+$

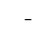

$+$

$+$

$+$

$-1+$

$-/+$

$+$

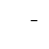

2. Subfornical organ

3. Median eminence

Internal

External

4. Area postrema 


\section{Figure Legends}

Figure 1 - Specificity controls for the MCHR1 antibody employed in this work. Widefield fluorescence photomicrographs of frontal brain slices obtained from male mice with different genotypes submitted to immunohistochemistry with or without antibodies and counterstained with DAPI (blue). A) Reaction in the presence of primary and secondary antibodies results in ample labeling of the nucleus accumbens; A') Omitting the primary antibody results in no labeling of cilia in the nucleus accumbens. Note that red fluorescence on the anterior commissure and matrix of the caudate-putamen are caused by overexposure of the red channel, and do not represent specific labeling; $A^{\prime \prime}$ ) As is the case with the primary antibody, omitting the secondary biotinylated antibody also resulted in abolished labeling; B) The use of antibody PA5-24182 results in ample labeling of cilia in WT C57BL/6 mice; $\mathrm{B}^{\prime}$ ) In heterozygous mice, a clear reduction in the number of labeled cilia is observed; $\mathrm{B}^{\prime \prime}$ ) In homozygous Mchr1-1mice, no labeling can be observed. Abbreviations: ac - anterior commissure; ICj - islands of Calleja; LV - lateral

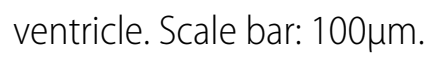

Figure 2 - The subcellular localization of MCHR1. Widefield fluorescence photomicrographs of frontal male mouse brain slices submitted to immunohistochemistry for adenylate cyclase III (green) and MCHR1 (red) and counterstained with DAPI (blue). A) In the pyramidal layer of the hippocampus, there is a large degree of colocalization between MCHR1 and AC3, as revealed by the merged yellow-orange labeling; $A^{\prime}$ ) Higher magnification of A. Immunoreactivity to MCHR1 is found in restricted areas of the AC3-positive cilia, varying in terms of coverage of the ciliary surface; B) Other areas, such as the granular layer of the dentate gyrus, are rich in AC3-ir cilia, but lack any MCHR1. Abbreviations: cc - corpus callosum; Ctx - cortex; GrDG - granular layer of the dentate gyrus; LMol stratum lacunosum moleculare of the hippocampus; MoDG - molecular layer of the dentate gyrus; $\mathrm{Or}$ - stratum oriens of the hippocampus; Rad - stratum radiatum of the hippocampus. Scale bar: A, B $=100 \mu \mathrm{m} ; \mathrm{A}^{\prime}=50 \mu \mathrm{m}$.

Figure 3 - Scale of MCHR1 immunoreactivity density. Widefield fluorescence photomicrographs of frontal mice brain slices submitted to immunohistochemistry for MCHR1 (red) and counterstained with DAPI (blue). The areas used to elaborate this scale are: accessory olfactory bulb $(0 \mid-)$, central medial thalamic nucleus $(1 \mid-/+)$, arcuate nucleus $(2 \mid+)$, basolateral nucleus of the amygdala $(3 \mid++)$, cortical layers 2 and $3(4 \mid++)$, paraventricular nucleus $(5 \mid+++)$, caudate-putamen $(6 \mid+++)$, pyramidal layer of the hippocampus proper $(7 \mid++++)$, and shell of the nucleus accumbens $(8 \mid++++)$. Scale bar: $100 \mu \mathrm{m}$.

Figure 4 - MCHR1 immunoreactivity in discrete prosencephalic areas. Widefield fluorescence photomicrographs of frontal mice brain slices submitted to immunohistochemistry for MCHR1 (red) and counterstained with DAPI (blue). A) The olfactory bulb contains one of the highest densities of ciliary MCHR1 in the mouse prosencephalon; B) Moderate to high densities of ciliary MCHR1 are found in layers 2, 3 and 5 of several cortical areas. A high density of labeling is observed in the caudate-putamen nucleus at this same level; C) A moderate density of cilia is observed in the preoptic periventricular nucleus of the hypothalamus. Some labeled cilia are also observed in the medial preoptic area; D) the paraventricular hypothalamic nucleus harbors one of the highest numbers of MCHR1-labeled cilia in the hypothalamus; E) Although only a few neurons contain neurons with MCHR1-harboring cilia in the incerto-hypothalamic area, this area can be clearly identified due to the lack of labeled cilia around it; F) The arcuate nucleus also contains a large number of immunolabeled cilia when compared to other hypothalamic nuclei, in particular in its ventromedial portion. Abbreviations: $3 \mathrm{~V}$ - third ventricle; AHA - anterior hypothalamic area; 
Arc - arcuate nucleus; cc - corpus callosum; CPu - caudate-putamen; EPL - external plexiform layer of the olfactory bulb; GrA - granular layer of the accessory olfactory bulb; GrO - granular layer of the olfactory bulb; IPL - internal plexiform layer of the olfactory bulb; IHy - incerto-hypothalamic area; LV - lateral ventricle; MPOA - medial preoptic area; Pe - periventricular preoptic nucleus; PVH - paraventricular hypothalamic nucleus; VMH - ventromedial

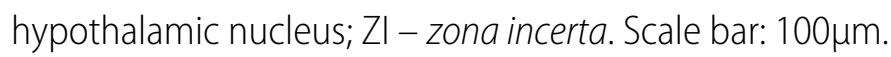

Figure 5 - Segregation of MCH and MCHR1 fields. Widefield fluorescence photomicrographs of a frontal male mouse brain slice submitted to immunohistochemistry for MCH (green) and MCHR1 (red), and counterstained with DAPI (blue). A) The septal area shows a clear segregation between MCH-ir fibers and MCHR1-ir cilia. A high number of fibers occupy the medial septal nucleus and only sparely innervate the shell of the nucleus accumbens, while MCHR1-ir cilia are found in the nucleus accumbens but not in the medial septal nucleus; A') Higher magnification of the delineated area in A. A clear MCH/MCHR1 boundary can be seen. Abbreviations: Acb - nucleus accumbens; CPu caudate-putamen; ICj - islands of Calleja; LSv - lateral septal nucleus, ventral part; LV - lateral ventral; MS - medial septal nucleus. Scale bar: $A=100 \mu m ; A^{\prime}=50 \mu m$.

Figure 6 - Differences between rats and mice concerning the distribution of MCHR1-ir cilia. Widefield fluorescence photomicrographs of frontal mice brain slices submitted to immunohistochemistry for MCHR1 (red). A, B) While the rat caudate-putamen displays a very high background and a very low number of immunoreactive cilia, the mouse caudate-putamen has a high number of immunoreactive cilia. C, D) The opposite is observed in the subgranular zone of the dentate gyrus. Although not abundant, rats display a strip of immunoreactive cilia in the subgranular zone, between the granular and polymorphic layers of the dentate gyrus. On the other hand, similar cilia are not observed in the mouse subgranular zone; $C^{\prime}, D^{\prime}$ ) Higher magnification of the delineated areas in $C$ and $D$. Abbreviations: CPu - caudate-putamen; GP - globus pallidus; GrDG - granular layer of the dentate gyrus; MoDG molecular layer of the dentate gyrus; PoDG - polymorphic layer of the dentate gyrus; SGZ - subgranular zone. Scale bar: $A-D=200 \mu m ; C^{\prime}, D^{\prime}=100 \mu m$.

Figure 7 - Neurochemistry identity of ciliary MCHR1-containing neurons in the glomerular layer of olfactory bulb. Confocal fluorescence photomicrographs of frontal mice brain slices submitted to immunohistochemistry for MCHR1 (red) and various neurochemical markers (green). A, A') Ample colocalization between MCHR1 and tyrosine hydroxylase in the glomerular layer of the olfactory bulb; B, B') Some colocalization is observed between calbindin and MCHR1, although in fewer numbers than MCHR1 and dopaminergic cells. Scale bar: $A, B=40 \mu m ; A^{\prime}, B^{\prime}=20 \mu m$.

Figure 8 - Neurochemistry identity of ciliary MCHR1-containing neurons in the hypothalamus. Widefield fluorescence photomicrographs of frontal mice brain slices submitted to immunohistochemistry for MCHR1 (red) and various neurochemical markers (green) counterstained with DAPI (blue). A, $A^{\prime}$ ) In the periventricular nucleus, some kisspeptin-ir cells have MCHR1-ir cilia; B, B') MCHR1-ir cilia are also seen in proximity to nuclei immunoreactive to estrogen receptor alpha in the periventricular nucleus; $C$ - D') In the paraventricular nucleus, MCHR1-ir cilia are found

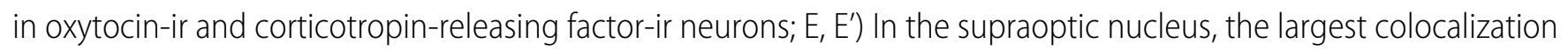
is between MCHR1-ir cilia and vasopressinergic cells; F, F') In the incerto-hypothalamic area, virtually every dopaminergic cell has a MCHR1-ir cilium. Abbreviations: 3V - third ventricle; AHA - anterior hypothalamic area; IHy incerto-hypothalamic area; LPO - lateral preoptic area; MeA - medial nucleus of the amygdala; MnPO - median 
preoptic nucleus; MPOA - medial preoptic nucleus; ot - optic tract; Pe - periventricular preoptic nucleus; PVH -

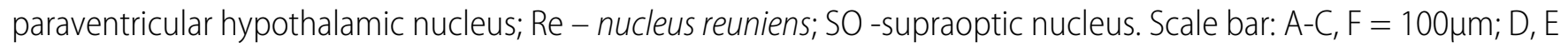
$=40 \mu m ; A^{\prime}-F^{\prime}=20 \mu m$.

Supplementary Material 01 - Colocalization between MCHR1-ir cilia and NeuN in the cortex. Widefield fluorescence photomicrographs of frontal mice brain slices submitted to immunohistochemistry for MCHR1 (red) and NeuN or DCX (green) counterstained with DAPI (blue). A, A') Cilia immunoreactive to MCHR1 largely colocalizes with NeuN, reinforcing that primary cilia-containing cells are neurons. B, B') There is no colocalization between MCHR1 and new neurons originated at the subgranular zone of the dentate gyrus. Abbreviations: 1 - cortical layer 1; 4 cortical layer 4; 6- cortical layer 6; cc - corpus callosum; GrDG - granular layer of the dentate gyrus; MoDG - molecular layer of the dentate gyrus; PoDG - polymorphic layer of the dentate gyrus. Scale bar: $A=100 \mu m ; B=40 \mu m ; A^{\prime}, B^{\prime}=$ $20 \mu \mathrm{m}$. 
bioRxiv preprint doi: https://doi.org/10.1101/755967; this version posted September 8, 2019. The copyright holder for this preprint (which was not certified by peer review) is the author/funder, who has granted bioRxiv a license to display the preprint in perpetuity. It is made available under ACC-BY-NC 4.0 International license.

Diniz et al, 2019

Ciliary MCHR1 in murines

FIGURE 1.tiff
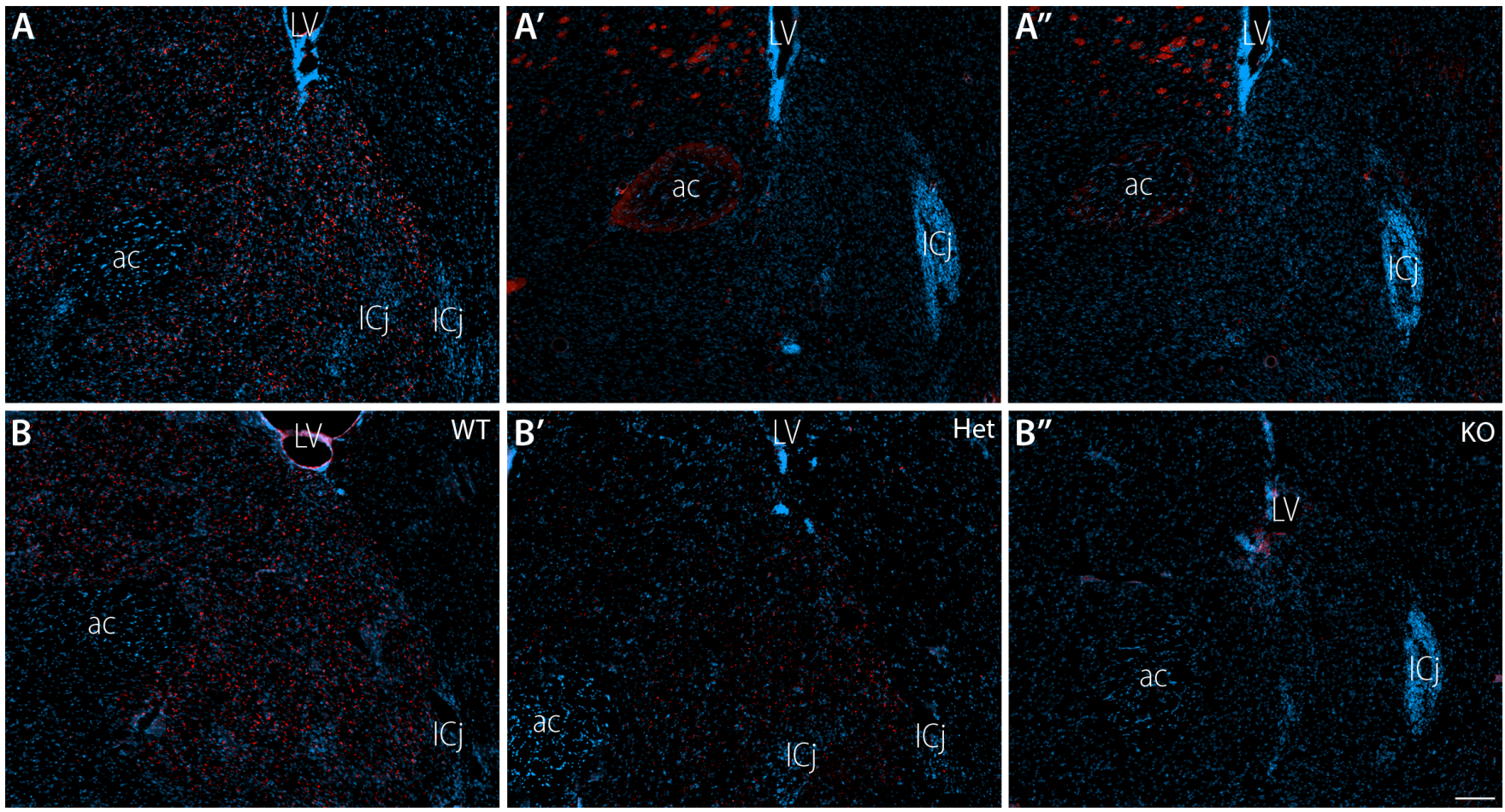

$B^{\prime \prime}$

$\mathrm{KO}$

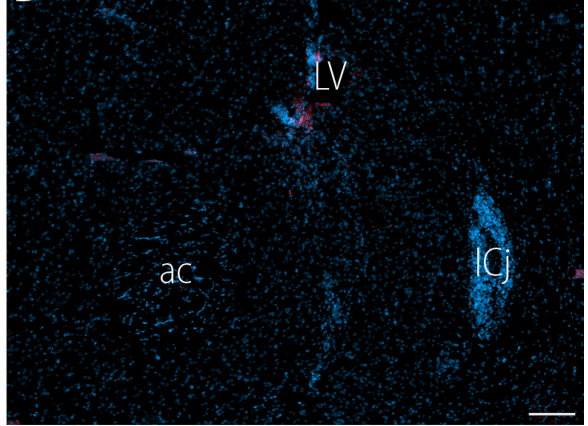


bioRxiv preprint doi: https://doi.org/10.1101/755967; this version posted September 8, 2019. The copyright holder for this preprint (which was not certified by peer review) is the author/funder, who has granted bioRxiv a license to display the preprint in perpetuity. It is made available under ACC-BY-NC 4.0 International license.

Diniz et al, 2019

Ciliary MCHR1 in murines

FIGURE 02.tiff
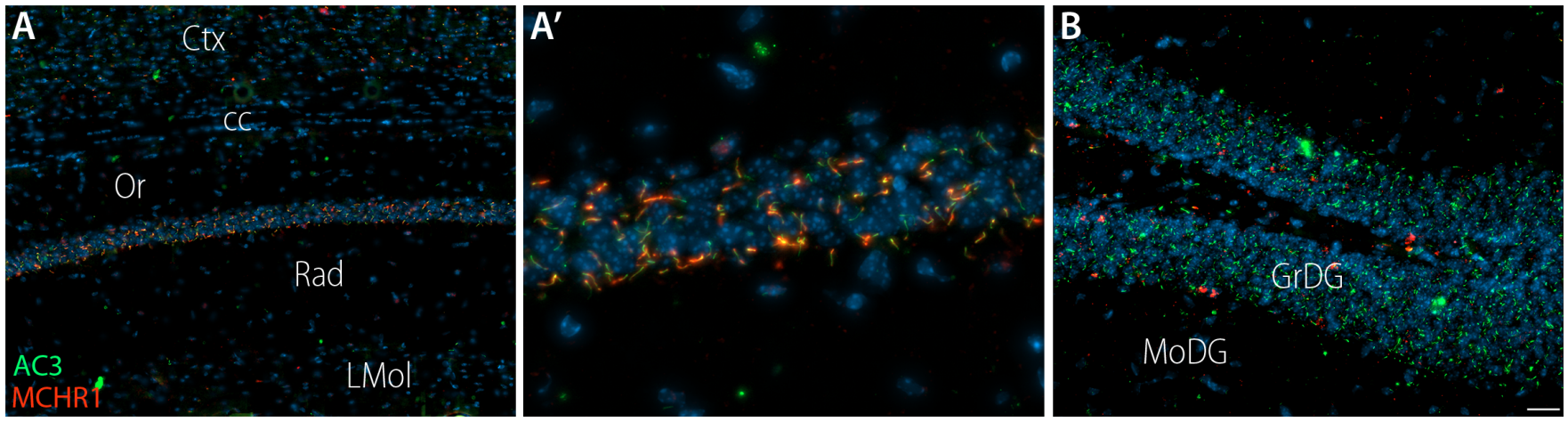
bioRxiv preprint doi: https://doi.org/10.1101/755967; this version posted September 8, 2019. The copyright holder for this preprint (which was not certified by peer review) is the author/funder, who has granted bioRxiv a license to display the preprint in perpetuity. It is made available under ACC-BY-NC 4.0 International license.

Diniz et al, 2019

Ciliary MCHR1 in murines

FIGURE 03.tiff
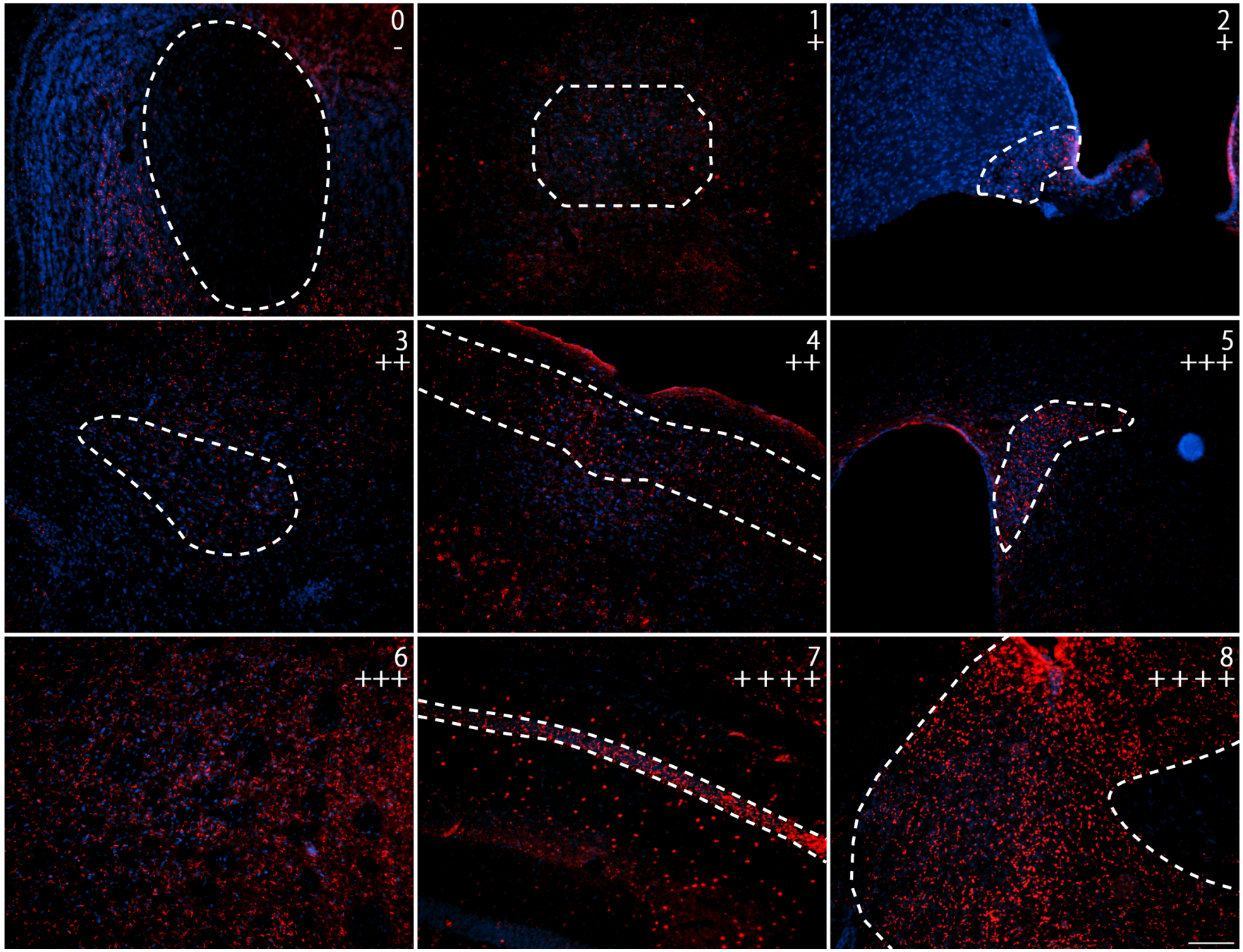
bioRxiv preprint doi: https://doi.org/10.1101/755967; this version posted September 8, 2019. The copyright holder for this preprint (which was not certified by peer review) is the author/funder, who has granted bioRxiv a license to display the preprint in perpetuity. It is made available under ACC-BY-NC 4.0 International license.

Diniz et al, 2019

Ciliary MCHR1 in murines

FIGURE 04.tiff
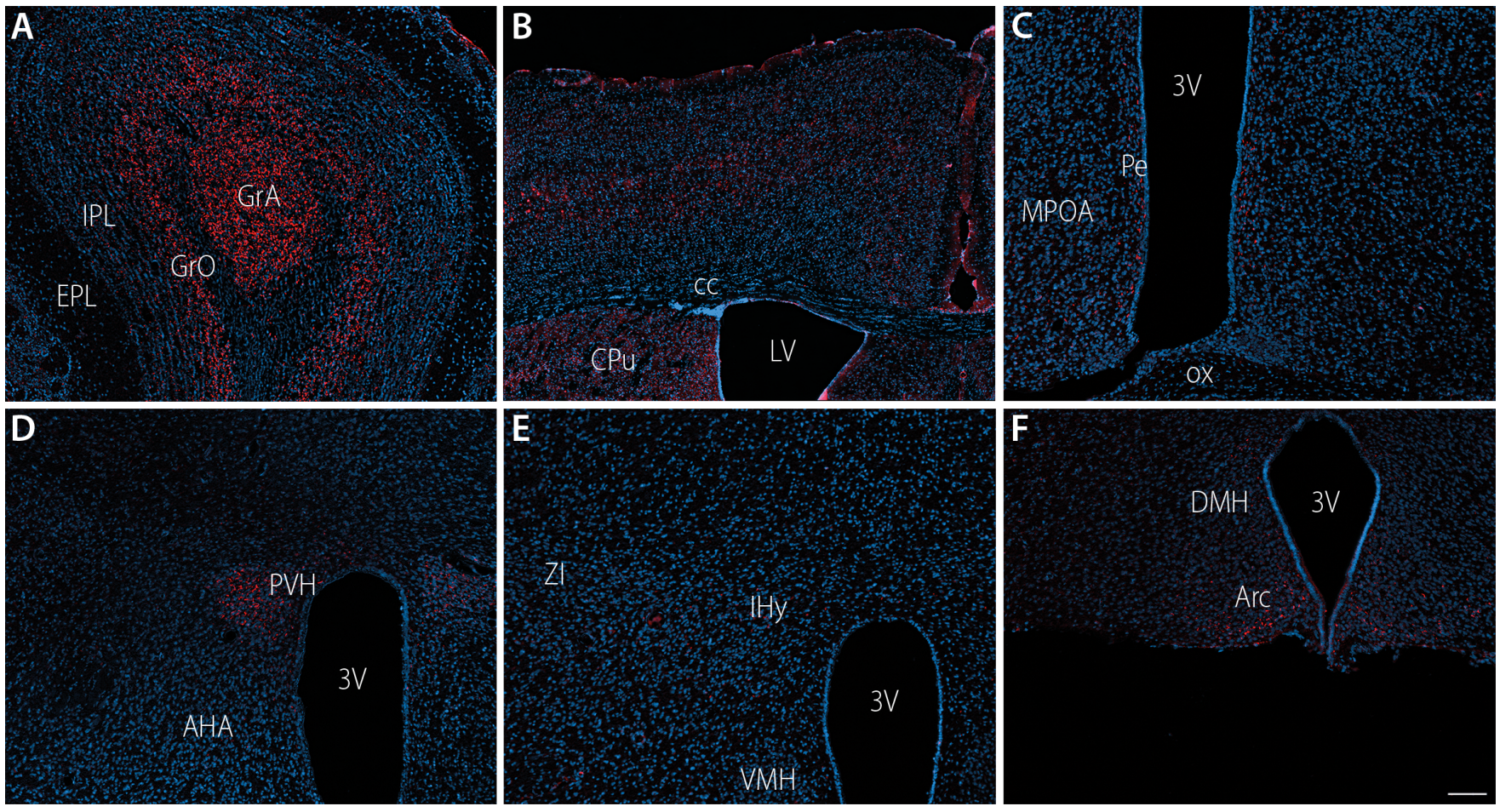
bioRxiv preprint doi: https://doi.org/10.1101/755967; this version posted September 8, 2019. The copyright holder for this preprint (which was not certified by peer review) is the author/funder, who has granted bioRxiv a license to display the preprint in perpetuity. It is made available under aCC-BY-NC 4.0 International license.

Diniz et al, 2019

Ciliary MCHR1 in murines

\section{FIGURE 05.tiff}
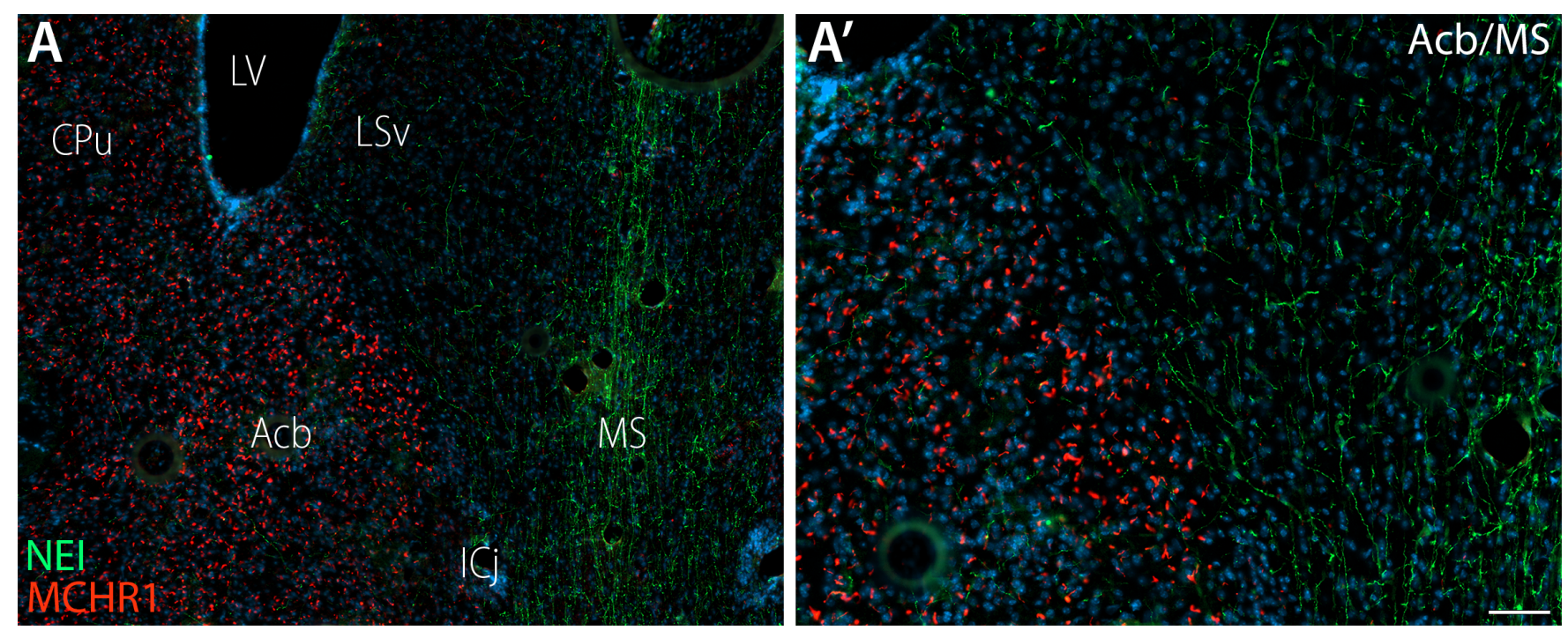
bioRxiv preprint doi: https://doi org/10,1101/755967; this version posted September 8, 2019. The copyright holder for this preprint (which was not certified by peer review) is the author/funder, who has granted bioRxiv a license to display the preprint in perpetuity. It is made available under aCC-BY-NC 4.0 International license.

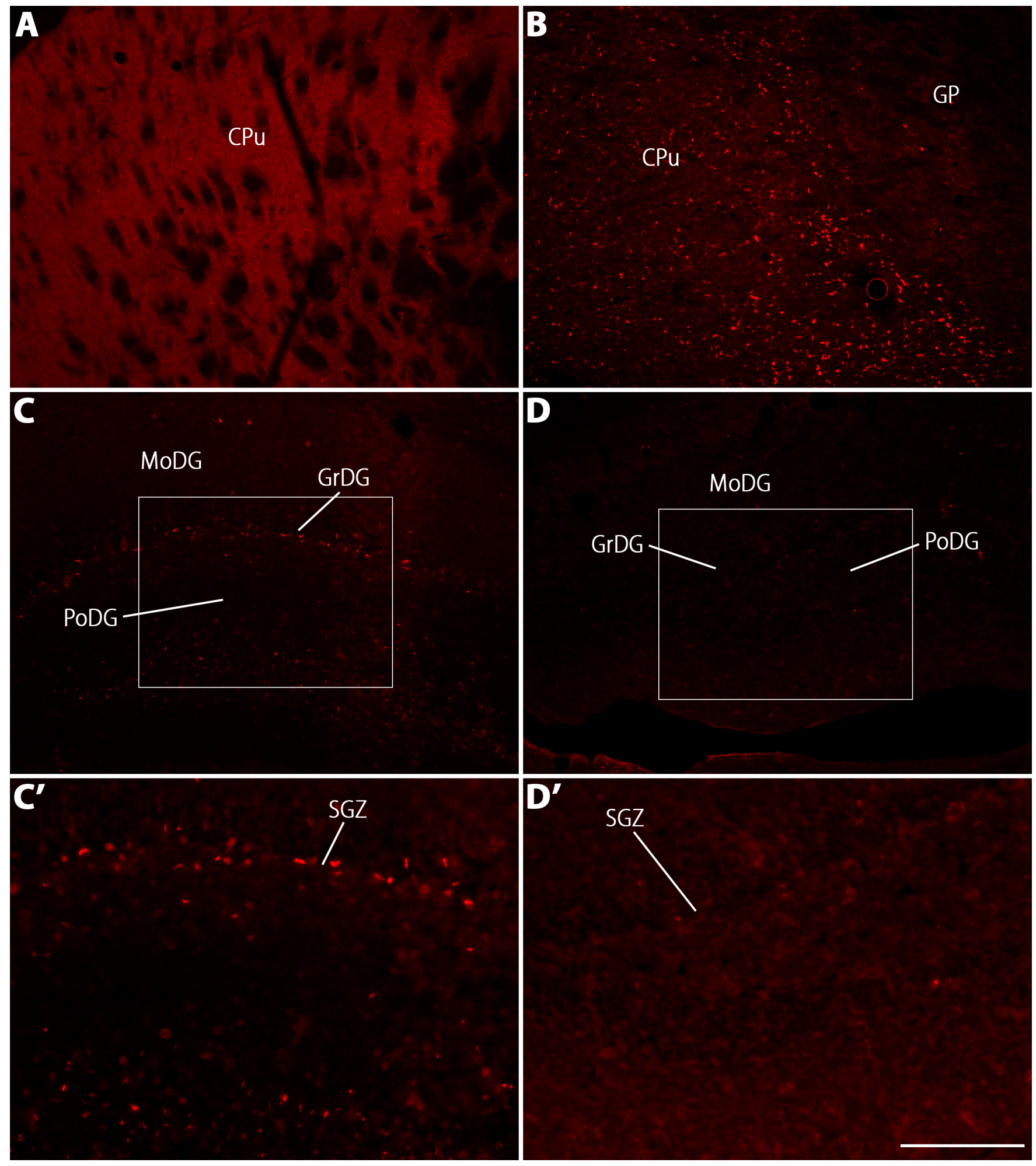


bioRxiv preprint doi: https://doi.org/10.1101/755967; this version posted September 8, 2019. The copyright holder for this preprint (which was not certified by peer review) is the author/funder, who has granted bioRxiv a license to display the preprint in perpetuity. It is made available under aCC-BY-NC 4.0 International license.

Diniz et al, 2019

Ciliary MCHR1 in murines

FIGURE 07.tiff

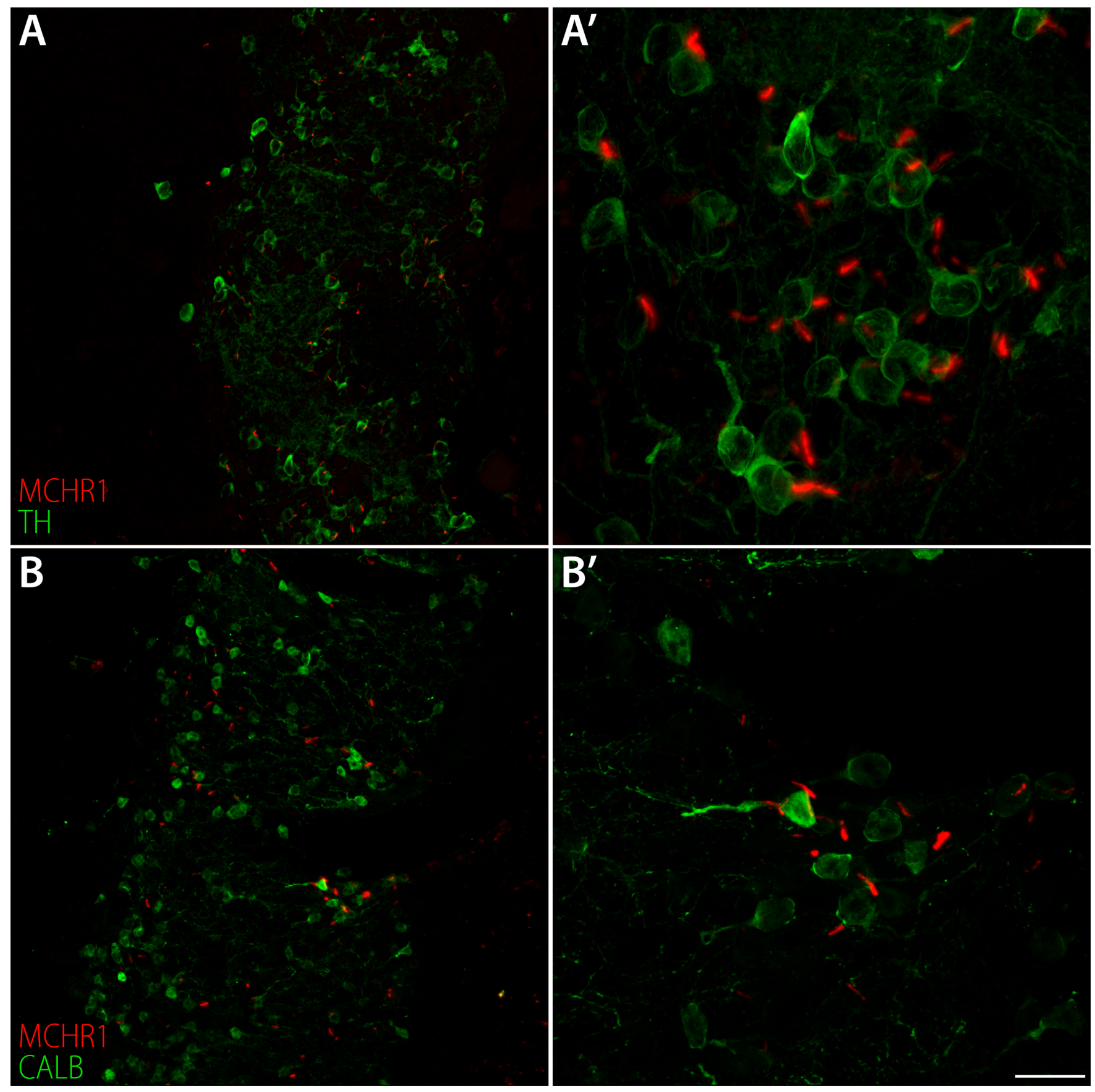


bioRxiv preprint doi: https://doi.org/10.1101/755967; this version posted September 8, 2019. The copyright holder for this preprint (which was not certified by peer review) is the author/funder, who has granted bioRxiv a license to display the preprint in perpetuity. It is made available under ACC-BY-NC 4.0 International license.

\section{FIGURE 08.tiff}
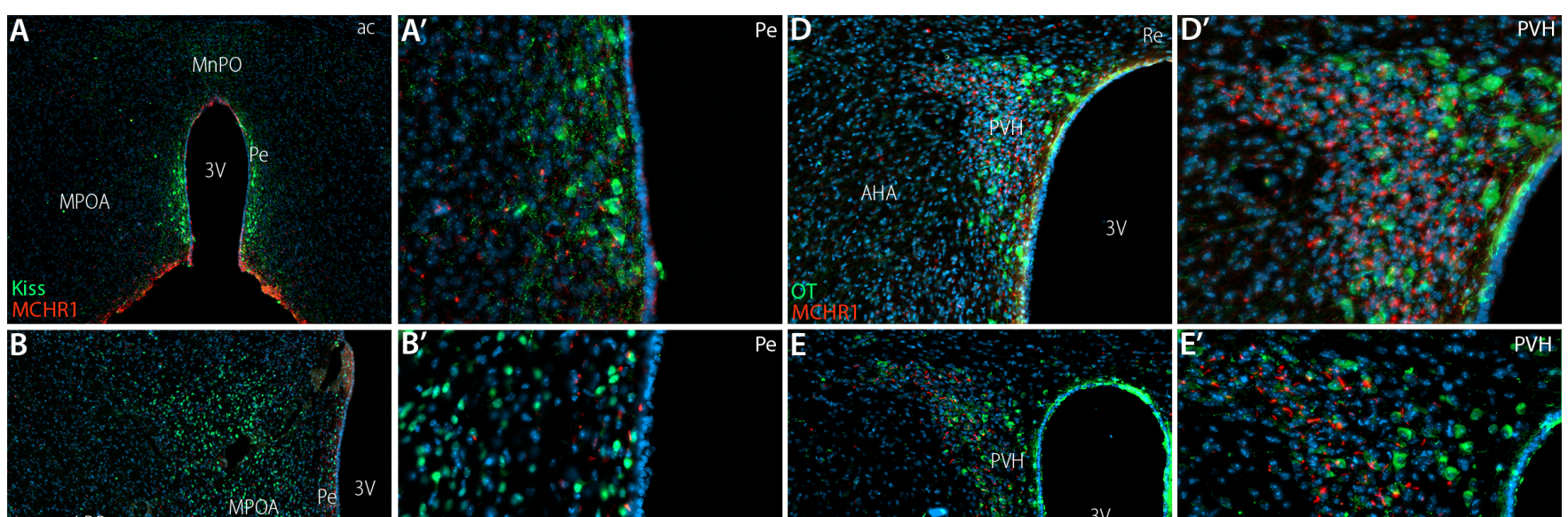

LPO
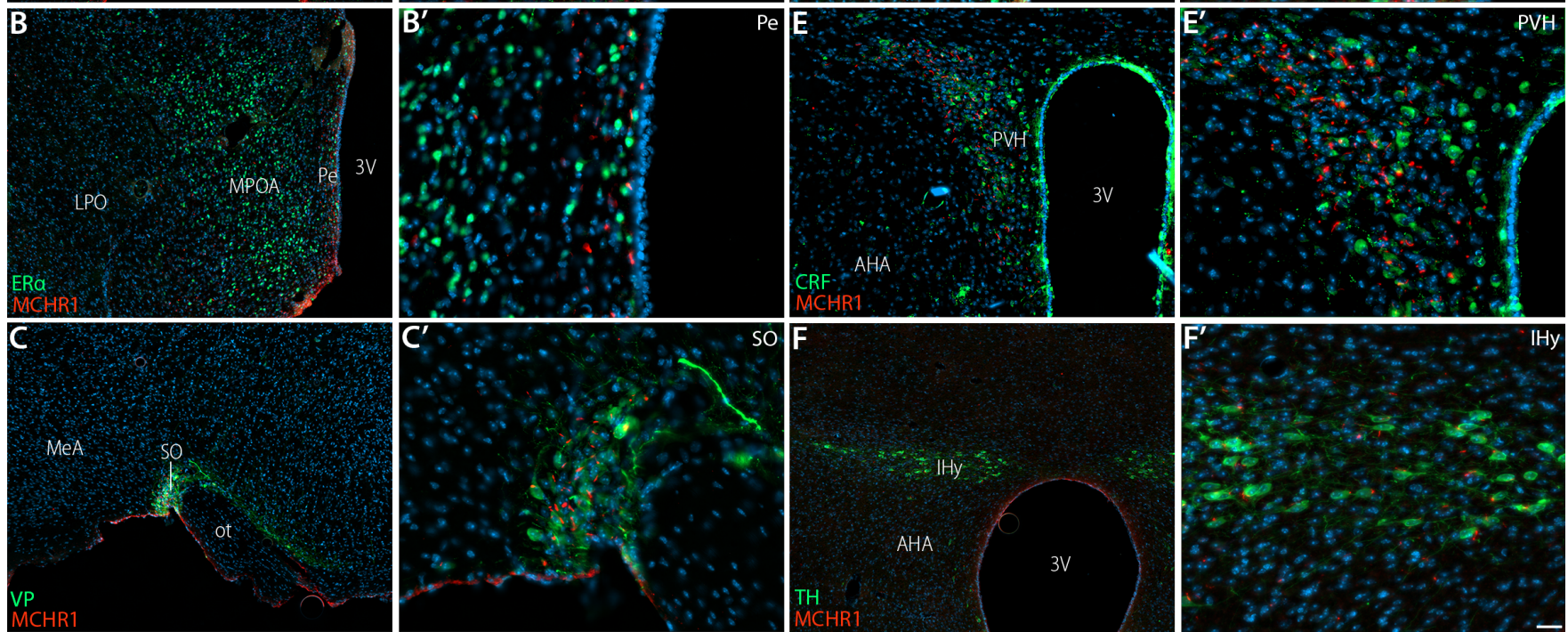